Summer 2004

\title{
Building the Northeast Asian Community
}

Byung-Woon Lyou

Indiana University School of Law

Follow this and additional works at: https://www.repository.law.indiana.edu/ijgls

Part of the Comparative and Foreign Law Commons, and the International Law Commons

\section{Recommended Citation}

Lyou, Byung-Woon (2004) "Building the Northeast Asian Community," Indiana Journal of Global Legal Studies: Vol. 11 : Iss. 2 , Article 8.

Available at: https://www.repository.law.indiana.edu/ijgls/vol11/iss2/8

This Note is brought to you for free and open access by the Law School Journals at Digital Repository @ Maurer Law. It has been accepted for inclusion in Indiana Journal of Global Legal Studies by an authorized editor of Digital Repository @ Maurer Law. For more information, please contact rvaughan@indiana.edu.

\section{$\Psi$}

JEROME HALL LAW LIBRARY

INDIANA UNIVERSITY

Maurer School of Law
Blooming ton 


\title{
Building the Northeast Asian Community
}

\author{
Lyou, Byung-WoON ${ }^{*}$
}

\section{Introduction: Regionalism, Globalization, and the Need for a Northeast Asian Economic Organization}

Asia is one of the most socio-politically divided regions in the world. Without regional cooperation, 'it faces difficulty in the world market, sometimes receiving unfair treatment. Asia contains more than half of the world's population, ${ }^{2}$ but Asian countries have a relatively small share of international organizations. ${ }^{3}$ Given these facts, it is meaningful to explore the need and legal basis for a Northeast Asian Community (NEAC), which would be an economically integrated regional trade association composed of Korea, China, and Japan. ${ }^{4}$

Within the last decade, the possibility of an East Asian regional trade agreement (RTA) or a much broader Asia-Pacific integration has been debated exten-

\footnotetext{
*Lecturer at Korea University School of Law, SJD (2003), LLM, Indiana University School of Law_Bloomington. LLD (completion of course-work), LLM (1997), LLB (1988), Korea University School of Law. I am deeply grateful to two professors: Former Dean Alfred Aman of Indiana University School of Law who provided expert guidance on globalization, constant support, and encouragement and Professor Lyou, Byung-Hwa, my brother, President of the Transnational Law and Business University and former Dean of Korea University School of Law who has taught me what law and a personality are. My study is affected by his works, especially International Law and The Philosophy of Law.

1. The lack of an institutional framework for dialogue and cooperation has been a distinctive feature of East Asia. See East Asia and the International System: Report of a Special Study Group 7 (Charles E. Morrison coord., 2001) [hereinafter East AsIa].

2. At present, the estimated world population is 6.3 billion, the Asian population is 3.8 billion, and the Northeast Asian population 1.5 billion (as described in note 4 , infra). WorLd Population 2002 Wallchart (U.N. population division, 2002) available at http://www.un.org/esa/population/ publications (last visited Mar. 18, 2004).

3. For example, the U.N. General Assembly Resolution 2847 (XXVI) states, "the 54 members of the [U.N. Economic and Social] Council should include 14 members from African States, 11 from Asian States, 10 from Latin American and Caribbean States, 13 from Western European and Other States, and six from Eastern European States." See G.A. Res. 2847, U.N. GAOR, 26th Sess., Supp. No. 29, at 67-68, U.N. Doc. A/RE.S/2847 (XXVI) (1971), available at http:// www.un.org/documents; Press Release, United Nations General Assembly, General Assembly Elects 18 New Members to UN Economic and Social Council, U.N. Doc. GA/9940 (Oct. 26, 2001), available at http://www.un.org/ News/Press/docs/2001/ga9940.doc.htm.

4. More precisely, China (including Hong Kong and Macao), Japan, South Korea, North Korea, Taiwan, and Mongolia.
} 
sively. ${ }^{5}$ Though not currently regionalized, Asia could be divided into three groups. ${ }^{6}$ In the Southeast Asian region, there is the Association of Southeast Asian Nations (ASEAN). ${ }^{7}$ ASEAN established the Asian Free Trade Area (AFTA) in 1993 and included Cambodia as its tenth member in 1999. In 1983, Australia and New Zealand organized the Australian/New Zealand Closer Economic Trade Relations Agreement (ANZCERTA) which has strengthened their cooperation with Asian countries, following the United Kingdom's entry into the European Union (EU). ${ }^{8}$ South Asia, the second regional group, is made up of India, Pakistan, Sri Lanka, and Bangladesh, whose economic contribution in Asia is relatively small. The group remains divided by religious conflicts and a contentious history. A third regional group, Northeast Asia, has the potential to develop into a similar economic community because of the increasing necessity of integration among neighboring countries.

A recently proposed formation of an East Asian Economic Caucus (EAEC) ${ }^{9}$ aimed to create an extended form of ASEAN, with China, Japan, and South Korea as its core states. ${ }^{10} \mathrm{~A}$ regional community requires a certain degree of cultural homogeneity, what is sometimes called "an inherent regional civil society." Given the strong societal differences between Northeast and Southeast Asia, it

5. See, e.g., John H. Jackson et al., Legal Problems of International Economic Relations 464 (3d ed. 1995).

6. Considering the current situation, it is reasonable to exclude Central and Western Asia.

7. ASEAN was established to accelerate economic growth, and social and cultural development, and to improve peace and stability in the region. ASEAN Declaration (Bangkok Declaration), Aug. 8, 1967, available at http://www.aseansec.org/1212.htm (last visited Mar. 18, 2004).

8. In 2002, AFTA-CER ministers established the Closer Economic Partnership (CEP). Ministerial Declaration of the AFTA-CER Closer Economic Partnership (Sept. 2002), at www.dfat.gov.au/ (last visited Mar. 3, 2004) [hereinafter Ministerial Declaration].

9. Originally, Malaysian Prime Minister Mahathir Mohamad proposed the formation of the East Asian Economic Grouping (EAEG) which was criticized by the United States. The East Asian Economic Caucus (EAEC) was formed in 2000 as a replacement. It is a diluted version of the EAEG and is envisaged as an informal consultative grouping of Asian nations. See Shim Jae Hoon \& Robert Delfs, Block Politics, FAR E. Econ. Rev., Nov. 28, 1991, at 26.

10. The EAEC consists of the ASEAN member states, plus Japan, Korea, and China ("ASEAN+3"). It provides a forum for North and Southeast Asia to discuss regional issues. See Santha Oorjitham, ASEAN+3 = "EAEC," Building Ties Across the Region, Mar. 15, 2000, at http:// www.asiaweek.com. Early warning mechanisms for trade, finance, and human security are on the agenda of the EAEC. Wendy K. Dobson, Deeper Integration in East Asia: Implication for the International Economic System, in EAST Asia, supra note 1, at 21.

11. Björn Hettne, Global Market versus Regionalism, in The Global Transformations Reader 159 (David Held \& Anthony McGrew eds., 2000). 
would be more workable to establish the NEAC, while Southeast Asia strengthens AFTA, than to extend ASEAN to encompass Northeast Asia. ${ }^{12}$

With the end of the Cold War, Asia-Pacific (including the Americas and Oceania) intergovernmental cooperation systems emerged from the Asia Pacific Economic Cooperation (APEC) process, in 1989. APEC is a loose organization which has regional, multilateral, and inter regional characteristics. ${ }^{13}$ "The subsequent Asia-Europe meeting (ASEM) established an inter-regional dialogue system between East Asia with the European Union." 14

A regional community like the $\mathrm{EU}^{15}$ established in Northeast Asia would provide several key benefits. Economically, the Northeast Asian countries would receive increased efficiency through economies of scale; increased productivity stimuli; strengthened bargaining power in the international market; and the "trade creation effect." Even though economic theory does not support such integration in every instance, a regional community, on the whole, improves its productive abilities with the creation of gains from trade.

The Heckscher-Ohlin ( $\mathrm{H}-\mathrm{O}$ ) theory (also called the factor-price equalization theorem), which is based on the theory of comparative advantage, postulates that welfare improvement within a community can be achieved through the exchange of goods created by each state's plentiful factors of production and through price equalization. ${ }^{16}$ Free trade in a regional community brings optimum allocative efficiency by use of specialized factors of production. Given an extended opportunity, the use of these specialized factors would result in economies of scale and productivity stimulation. This theory, however, is premised on

12. As the CEP shows, if the expectations of the two regions have been met, the scope of the regional agreements would expand by a "spill-over" effect. See Ministerial Declaration, supra note 8; Winfried Lang, New Regionalism in a Changing World Order, in International Law: Theory and Practice 45 (Karel Wellens ed., 1998).

13. "APEC is not an exercise in regional integration but intergovernmental cooperation." Richard Higgott, The International Political Economy of Regionalism: The Asia-Pacific and Europe Compared, in Regionalism and Global Economic Integration: Europe, Asta and the Americas 49 (William D. Coleman \& Goeffrey R.D. Underhill eds., 1998). The authors call it a "market-led open regionalism." Id. at 43. For a more detailed description of how APEC developed, see id. 42-49.

14. See East Asia, supra note 1 , at 7.

15. The Asia-Pacific region could look to Europe for empirical and theoretical insight. Higgott, supra note 13 , at 42.

16. David Ricardo's comparative advantage and H-O theory support free trade, which is no longer considered a zero-sum game. See Thomas A. Pugel \& Peter H. Lindert, International Economics 52-57 (11th ed. 2000). 
the idea that each country participant has different, plentiful factors of production and that these factors are homogenous.

A RTA brings with it two kinds of trade effects. One is the trade creation effect: this refers to the expansion of trade with efficient suppliers inside the community. The other is the "trade diversion effect," which refers to a shift in trade from the efficient suppliers outside the community. to inefficient suppliers located inside it. ${ }^{17}$ If the trade creation effect is larger than the trade diversion effect, then economic integration will bring a Pareto improvement. In the EU, regional integration has led to gains of about one percent of GDP. ${ }^{18}$ Moreover, the unmeasured dynamic gains that come from economies of scale and productivity stimuli make the net effect much larger. ${ }^{19}$ Even though some social losses can take place through integrated policies, such as the EU's Common Agricultural Policy (CAP), ${ }^{20}$ these are the harmonization costs for the integration. Through the establishment of a regional community, the Northeast Asian countries could reduce these negative integration effects.

Socio-politically, the Northeast Asian countries would strengthen their positions in international organizations and societies as a result of integrating into a regional economic community. The EU deals effectively with the United States by using a single discussion channel in matters like trade and disputes settlement, while Korea, Japan and China tackle the problems individually and often ineffectively. Increased exposure to the effects of international markets requires not only domestic policy adjustments but also a collective policy arrangement. ${ }^{21}$ Isolation also creates problems in electing or appointing officials to international organization; Asian countries are thus often unfairly treated. Thus, the countries need a push forward to create a regional community.

17. See JaCkson et AL., supra note 5 , at 465.

18. See Pugel \& Lindert, supra note 16, at 220.

19. The 1988 Cecchini Report estimated a 5 to 6 percent net increase of the EU's GDP. See Paolo Cecchini et al., The European Challenge 1992: The Benefits of a Single Market (1988); Michael Emerson et al., The economics of 1992: The E.C. Commission's Assessment of the Economic Effects of Completing the Internal Market 1-10 (1988); Paul Craig \& Gráinne de BúrCa, EU Law 1166 (3d ed. 2003).

20. See George A. Bermann et al., Cases and Materials on European Community Law $1063-1100$ (1993).

21. "The Union shall in particular ensure the consistency of its external activities as a whole in the context of its external relations, security, economic and development policies." The Treaty on European Union, Nov. 1, 1993, as amended by the Treaty of Amsterdam, May 1, 1999, art. 3 [hereinafter TEU]. 
Transition from relative heterogeneity to increased social homogeneity in areas such as culture, economic policies, and security, in fact, is the process of regional integration. ${ }^{22}$ Northeast Asia, in which social homogeneity is ahistorical, lacks experiences of social interchange, and in this sense is fundamentally different from Europe. Even though the Chinese Character culture, Confucianism, and Mahayana Buddhism influenced all of Northeast Asia considerably, ${ }^{23}$ historically there have been only minimal diplomatic interchanges between governments and only small-scale, unofficial trade in the frontier areas. ${ }^{24}$ Moreover, the Northeast Asian countries' levels of economic development differ greatly. Certain requirements must be attained before progressing to new levels of economic integration, and basic socio-cultural factors may limit this process, as is evident from European integration. ${ }^{25}$ Until now, the Northeast Asian peoples have not realistically considered regional integration, because of gaps in social homogeneity, poor experiences in social exchanges, and differences in economic development. However, there is increasing recognition of the need for a Northeast Asian organization that reflects competitive regionalism and globalization.

Regionalism can be approached in several ways. One approach, which is rooted in the neo-functionalists' theory, describes regionalism as the incremental creation of regional institutions in response to various functional demands, such as enhancing the economic welfare of participating states. ${ }^{26}$ Another approach, rooted in federalist theory, is the model of fair distribution of power and competence at a level below a global organization. ${ }^{27}$ This approach, known as "constructivism," focuses on the communal identity in regional integration. ${ }^{28}$ In

22. Hettne, supra note 11 , at 159.

23. Ho-Chul Lee \& Mary P. McNulty, East Asia's Dynamic Development Model and the Republic of Korea's Experiences, World Bank Policy Research Working Paper 2987, at 6 (Mar. 2003), available at http://econ.worldbank.org/files/24755_wps2987.pdf (last visited Mar. 18, 2004).

24. Concerning the past relationship among Korea, China, and Japan, see William E. Henthorn, A History of Korea 152-58 (1971); Kenneth B. Lee, Korea and East Asia: The Story of a Phoenix 95-114 (1997); Quansheng Zhao, China and the Two Koreas, in The Two Koreas and the United States 130, 134 (Wonmo Dong ed., 2000).

25. JACKson, supra note 5, at 211.

26. Lang, supra note 12, at 45; Edward D. Mansfield \& Helen V. Milner, The Political Economy of Regionalism: An Overview, in The Polrtical Economy of Regronalism 5-8 (Edward D. Mansfield \& Helen V. Milner eds., 1997).

27. Lang, supra note 12 , at 45.

28. See Charles A. Kupchan, Regionalizing Europe's Security: The Case for a New Mitteleuropa, in The Political Economy of Regionalism, supra note 26, at 209-15. 
constructivism, regional integration is "ideational products." 29 This approach emphasizes collective security, rather than a functional or economic need for the regional integration. ${ }^{30}$ This Note focuses on the neo-functionalist theory, since the main purpose of the NEAC would be the Pareto improvement of its members.

Presently, the causes of regional integration are primarily economic. When NATO lost its original "raison d'être," regionalism faced a new situation: while security considerations became less salient, economic development became a central issue. Neo-functionalism has to meet new threats, such as environmental risks, drug-trafficking, and global terrorism. ${ }^{31}$ In addition to regionalism, globalization complicates these issues. Globalization is described as "flows of trade and finance between the major regions in the world economy, while equivalent flows within them can be differentiated in terms of local, national and regional clusters." 32 Both globalization and regionalism stimulate the interchange of goods and finance as well as the integration of subunits. Globalization and regionalism are thus both types of integration.

Regionalism continuously influences all aspects of life, from culture to politics to the economy. "Within the economic, or trade realm, the impact of regionalism has been especially pronounced." ${ }^{33}$ Mass regionalism, rooted in neo-functionalism, was initiated after the collapse of the Cold War regime and with the beginning of WTO system. ${ }^{34}$ Europe has since been rearranged as a successful regional community. The United States has free trade agreements (FTAs) with Canada and Mexico

\section{Id.}

30. See id. at 209, 211-15.

31. See Towards an East Asian Community: Region of Peace, Prosperity and Progress, East Asia Vision Group Report 2001, at 18, para. 65, at http://www.mofa.go.jp/region/asia-paci/ report2001.pdf (last visited Mar. 18, 2004) [hereinafter East Asia Vision Group Report]; Lang, supra note 12, at 47; see also 2001 ASEAN Declaration on Joint Action to Counter Terrorism, 7th ASEAN Summit and the 5th ASEAN + 3 Summit, Nov. 5, 2001, available at http://www .aseansec.org/529.htm (last visited Mar. 18, 2004); APEC Leaders Statement on Counterterrorism, Oct. 21, 2001, at http://www.chinaembassy-org.be/(last visited Mar. 18, 2004).

32. See David Held et al., Rethinking Globalization, in The Global Transformations Reader, supra note 11 , at 55 .

33. Sungioon Cho, Breaking the Barrier between Regionalism and Multilateralism: a New Perspective on Trade Regionalism, 42 Harv. Int'L L.J. 419, 419 (2001).

34. See JACKson, supra note 5, at 464-65. "As the globalism of today is different that during the 1920 s, regionalism of today is different than the 'destructive regionalism' of the 1930s that set the stage for the creation of exclusive blocs, deepened the impact of the Great Depression, and 
(NAFTA) as well as with Israel. At the Summit of the Americas, heads of state representing thirty-four American countries have reaffirmed their political commitment to strengthen hemispheric relations by approving the finalization of a Free Trade Area of the Americas (FTAA) by January 2005. ${ }^{35}$ In Latin America, not only may a broad Latin American free trade area result through a combination of the MERCOSUR and Andean Pacts, but that free trade area itself may be merged with NAFTA into the FTAA. In addition to ASEAN (AFTA) in Asia, some regional groups in central, eastern, and southern Africa have formed a continentwide African Economic Community (AEC).

The growth of country membership in the WTO has not adversely affected the growth of regionalism. "Over 170 RTAs are currently in force." ${ }^{36}$ In fact, global flourishing of RTAs makes Northeast Asian countries feel isolated. Globalization can also be defined as the growing integration of world markets, which brings denationalization of politics, markets, and laws. While China and North Korea have insisted on nearly absolute state sovereignty, there are increasing limitations on that sovereignty because of these globalizing trends..$^{37}$ Globalization asks for a combination of self-rule and shared rule..$^{38}$

From the late 1960s to early 1970s, because of the disappointment from the post-colonial policies, Third.World states applied regionalist practices toward trade and economic cooperation among the developing countries. During the Cold War, this regional hegemony created a sort of league of non-allied states. This regionalism, which was used by the Third World as a justification for the adoption of domestic policies such as socialism and the protection of infant national industries, did not advance globalization. ${ }^{39}$

ultimately resulted in the Second World War. For example, the EU is working on extending to the East European countries through supporting them." Dennis Kennedy, Regional Trading Blocs, Multilateralism and the New GATT Agreement: An Introduction, in Regional Trade Blocs, Multilateralism, and The GatT: Complementary Paths to Free Trade 1 (Till Geiger \& Dennis Kennedy eds., 1996).

35. In order to lower the trade barriers of South American and Caribbean countries, which are 3.5 times higher than that of the United States, the United States pushed toward free trade agreements. See Robert J. Carbaugh, International. Economics 262 (1998).

36. See WTO, Regional Trade Agreements, at http://www.wto.org/ (last visited Mar. 15, 2004); Teshome Mulat, Multilateralism and Africa's Regional Economic Communities, 32 J. World Trade 115, 116 (Aug. 1998).

37. See generally Daniel J. Elazar, Constitutionalizing Globalization 17-22, 32-35 (1998).

38. Id. at 200.

39. See Mulat, supra note 36, at 115; see also Lang, supra note 12, at 45-46. 
By contrast, the popular paradigm today is free trade, globalization, and substantial growth through competition. ${ }^{40}$ GATT' ${ }^{41}$ article XXIV ${ }^{42}$ restricts the formation of regional fortresses, ${ }^{43}$ or exclusive economic blocs. It requires that any modern regionalism not be a malignant form but rather a bona fide form, one favorable to globalization. The regionalism of today cannot afford to be inward-looking because globalization has made markets more and more interconnected and interdependent. ${ }^{44}$ With GATT article XXIV, which makes regionalism compatible with multilateralism, globalization has broken down the traditional dichotomy between regionalism and multilateralism.

The regionalism of today ${ }^{45}$ responds to three aspects of globalization: the replacement of domestic markets by international markets; ${ }^{46}$ the decline of geographical determinants of money and labor; the continued intensification of multinational and private policy-making structures. ${ }^{47}$ Thus, a benign form of regional integration has a positive effect on global trade liberalization. Globalization and regional integration can be seen as complementary processes, modifying each other, in the formation of a new world order, even though they may

40. All of these are themes of the UNCTAD report. Globalization, Competition, Competitiveness and Development, U.N. Trade and Development Board, 44th Sess., U.N. Doc. TD/B/44/20 (1998), available at www.unctad.org/en/docs/(last visited Mar. 19, 2004).

41. General Agreement on Tariffs and Trade, Oct. 30, 1947, 55 U.N.T.S. 194 [hereinafter GATT 1947], as amended by the Marrakesh Agreement, Establishing the World Trade Agreement, Jan. 1, 1994 [hereinafter WTO Agreement]; GATT 1947, as amended, supra, Annex 1 A, 33 I.L.M. 1153 (1994) [hereinafter GATT]; Understanding on the Interpretation of Article XXIV of GATT, in GATT 1947, as amended, supra, Annex 1A(1)(d), 33 I.L.M. 1160 [hereinafter XXIV Understandingl.

42. Especially GATT, supra note 41 , art. XXIV paras. 4, 5(a).

43. A regional fortress could challenge the WTO. See Lang, supra note 12, at 46; Bernard M. Hoekman \& Michel M. Kostecki, The Political Economy of the World Trading System: The WTO and Beyond 360-61 (2d ed. 2001).

44. See Japan-Singapore Economic Agreement for a New Age Partnership: Joint Study Group Report (2000), available at http://www.mof.go.jp/jouhou/kanzei/kal40115b2.pdf (last visited Apr. 1, 2004) [hereinafter JSEPA Study Group].

45. "The geographical, historical, political and cultural contexts are sufficiently different as to ensure different paths towards regional co-operation, but the context of managing regional economic policy co-ordination in an era of globalization is the same for both European and Asian actors." Higgott, supra note 13 , at 42.

46. While world GDP grew by six times between 1950 and 2000, international trade multiplied by twenty times. In 1999, international trade represented 18 percent of the world GDP, compared to 9 percent in 1965 . See JSEPA Study Group, supra note 44 , at $\$ 1-4$.

47. See generally Susan Strange, The Defective State, 124 DaEdalus 55 (1995). 
be based on different situations or concrete issues. ${ }^{48}$ Another important force, accelerating change in production and consumption patterns, is the rapid progress of information and communications technology. ${ }^{49}$ The Internet, an important method of doing business today, has contributed to a borderless global economy ${ }^{50}$ by removing physical distance.

In this recognition of these trends, Northeast Asia has shifted its attention more and more toward the development of an institutional expression of its own identity. ${ }^{51}$ In the past, Japan regarded the EU and the United States as its main trade partners and was not very interested in its neighbor countries. In recent years, there are remarkable signs that the Japanese are rediscovering their regional identity, economically exemplified by Japan's vigorous promotion of the Japan-Korea Free Trade Agreement (JKFTA). ${ }^{52}$ The JKFTA could induce China to participate in a regional community. China's WTO participation with Taiwan in $2001^{53}$ will promote free trade in this area once more. With China's participation in the WTO, the WTO framework could serve as a common adivisor of Northeast Asia, accelerating trade regionalization. Moreover, both the APEC and the ASEM have moved in recent years to keep up the momentum of their early years.

48. See Hettne, supra note 11, at 156. "In many respects, globalization has crept up upon us and the mechanisms developed to promote it such as the WTO or the EU and their regional counterparts" ElazAR, supra note 37, at 3.

49. See JSEPA Study Group, supra note 44.

50. "A globalized economy run by overlapping and interconnected networks of state and nonstate actors in both public and private domains is mitigating the significance of space and territory." Higgott, supra note 13, at 59.

51. See East Asia, supra note 1, at 4.

52. See Japan-Korea Free Trade Agreement Joint Study Group Report (2003), available at http// www.mofa.go.jp/region/asia-paci/korea/index.html (last visited Mar. 19, 2004) [hereinafter JKFTA Joint Study]. Japan agreed with Singapore on the Japan-Singapore Economic Agreement for a New Age Partnership (JSEPA). See Joint Announcement by the Japanese and Singapore Prime Ministers on the Completion of Negotiations of the JSEPA, Oct. 20, 2001, available at http:/www.mofa.go.jp/ region/asia-paci/singapore/ jsepa0110.html (last visited Mar. 19, 2004). Korea also promotes the Korea-Singapore Free Trade Agreement (KSFTA). See KSFTA Joint Study Group Report (2003), available at http://www.mti.gov.sg/public/PDF/CMT/FTA_KSFTA_JSG_Report.pdf (last visited Mar. 19, 2004).

53. WTO, Accession of the People's Republic of China, WT/L/432, Nov. 23, 2001, available at http://www.wto.org/ (last visited Mar. 19, 2004). 
Northeast Asia has a successful model of a regional community in the EU..$^{54}$ In the case of the two Koreas, it should be noted that the unification of Germany was achieved with the integration of West Europe, and the formation of the EU. ${ }^{55}$ The unification of the two Koreas can be aided through a regional integration process as well. A considerable part of the unification cost, like EU's various integration funds, ${ }^{56}$ would be the cost of North Korea's accession to the NEAC. The China-Taiwan problem is somewhat different; Taiwan does not seek unification with China. The NEAC integration could be the answer to the problem. If the process involved substantial integration, asking a partial restriction on sovereignty, under supranational control, not only could it ease Taiwan's apprehension of being absorbed by China, but also it could give China the same effect of two regimes under one state.

It is important that the NEAC not act as a "regional fortress." Essentially, the NEAC should not take regional protectionist measures. Such action would be taken as a threat by non-members. ${ }^{57}$ As the trial of EAEC was considered by the United States to encourage economic rivalry with Japan, ${ }^{58}$ similar regional exclusiveness also could be considered a hegemonic stance. The NEAC not only should have good relations with the rest of the world, but also should pursue the common good of the world. A benign form of regional integration does not imply division of international society, because it strengthens the organizing international or global society through the integration of regional unit. Good empirical evidence suggests that the general political opposition of third countries to the EU, and its exercise of international legal rights, has now largely disappeared. ${ }^{59}$

This Note is composed of three main parts. Part II will define the proposed NEAC. Focused on an economic integration and WTO rules, in order to define

54. "Europe is also a concrete model often referred to as an example to follow by other regional organisations." Hettne, supra note 11 , at 159.

55. Masao Okonogi, The North Korean Crisis and Japan's Choice, in The Two Koreas and the United States 119, 1 19-29 (Wonmo Dong ed., 2000).

56. See Pier Carlo Padoan, Regional Agreement as Clubs: The European Case, in The Political Economy of Regionalism, supra note 26, at 107, 115-16 (discussing integration in general).

57. The inherent exclusiveness of a regional economic community conflicts with the interests of non-members. See Cho, supra note 33 , at 420 .

58. Malaysia expected Japan's leading role. See Anthony Rowley, The Malaysian Two-Step, Far E. Econ. Rev., Apr. 18, 1991, at 70-71.

59. See Eileen Denza, The Community as a Member of International Organizations, in The European Union and World Trade Law: After the GATT Uruguay Round at 3, 15 (Nicholas Emiliou \& David O’ Keeffe eds., 1996). 
the NEAC, the present Northeast Asia situation and a reasonable degree of integration for countries in the region and the empirical implications of the EU should be considered. Part III discusses the economic necessity of the NEAC. This part explains the "custom factory effect," ${ }^{10}$ derived from the NEAC integration. This part also shows the current degree of regionalization of Northeast Asia, by surveying the international transactions among the Northeast Asian states and analyzing the economic effects, such as the intensity index of trade, through formulae and statistics. Part IV explores the socio-political requirements for Northeast Asian countries to be able to integrate. This part seeks a way to meet these requirements, namely a potential method for the establishment of the NEAC. Then, this Note draws conclusions.

\section{Defining the NEAC under GATT article XXIV}

\section{A. Approach to a Definition of the NEAC}

\section{Factors in the Definition}

Nowadays, when global security considerations have become less salient, the causes of regional integration, unlike those of the Cold War period, are mainly economic. Thus, the formation of the NEAC should focus on the economic interests of the Northeast Asian countries. The NEAC, a Regional Trade Association, should be regulated by GATT article XXIV, as an exception to the Most Favored Nation principle (MFN), which is the main structure of the World Trade Organization. In order to define the NEAC, while focusing on economic interest and WTO rules, the present Northeast Asia situation and the plausible degree of integration should also be considered. The empirical evidence of the EU, especially the progress that its constituent communities are making toward increasing integration, could act as a signal and direction for the NEAC.

\section{GATT article $X X I V$}

RTAs, including Customs Unions (CUs) and Free-Trade Areas (FTAs) are permitted only to the extent that they comply with the provisions of GATT 
article XXIV, especially paragraphs $5,6,7$ and $8 .{ }^{61}$ Paragraph 5 requires that the level of tariffs and other commercial regulations in following integration not be "on the whole" higher or more restrictive than "the general incidence" 62 of the regulations prior to integration. ${ }^{63}$ Paragraph 5 also provides that any interim agreement shall include a plan and schedule for the formation of an RTA within "a reasonable length of time." 64

In paragraph 6, the procedure of GATT article XXVIII shall apply if a member of the regional community (CU) proposes to increase any tariff rate inconsistent with the state's schedules of concession according to GATT article II. ${ }^{65}$ Paragraph 7 requires that any state deciding to enter into an RTA shall promptly notify the members and shall make available to them information regarding their entry into that regional integration; ${ }^{66}$ that if it is not likely that a regional community will be formed according to plan and schedule, the members shall make recommendations to the party to enter into a regional integration; ${ }^{67}$ and that any substantial change in the plan or schedule concerning the interim agreement shall be communicated to the members. ${ }^{68}$ Paragraph 8 asks that tariffs be eliminated with respect to "substantially all the trade" between or among members with respect to substantially all the trade in products originating in such territories in the regional community. ${ }^{6}$ ?

Until recently, GATT article XXIV has not regulated regional integration well in a legal sense. Over fifty previous Working Parties on economic integration have been unable to reach unanimous conclusion as to an agreement for integration of GATT consistency, although no such agreement has been explicitly disapproved. ${ }^{70}$ WTO members may approve regional integration by a two-

61. See XXIV Understanding, supra note 41 , at 1161 paras. $1,5$.

62. Id. at para. 2. "The evaluation under paragraph 5(a) of Article XXIV of the general incidence of the duties and other regulations of commerce applicable before and after the formation of a customs union shall in respect of duties and charges be based upon an overall assessment of weighted average tariff rates and of customs duties collected." Id.

63. GATT 1947, supra note 41, at art. XXIV: 5.

64. XXIV Understanding, supra note 41, at 1162.

65. GATT 1947, supra note 41, at art. XXIV: 6.

66. Id. at art. XXIV: 7(a).

67. Id. at art. XXIV: 7(b).

68. Id. at art. XXIV: 7(c).

69. Id. at art. XXIV: 8.

70. GaTT, Analytical Index: Guide to GaTT Law and Practice 760 (6th ed. 1994). 
thirds majority, even if such integration does not fully comply with the requirements of GATT article XXIV. ${ }^{71}$ Furthermore, it is hard to say that GATT article XXIV, paragraph 4 is legally binding. ${ }^{72}$ GATT article XXIV, however, should be strictly interpreted because it is the exception to the main pillar of the WTO.

The purpose of GATT article XXIV is to permit regional integration without unduly diluting the MFN principle. ${ }^{73}$ The XXIV Understanding ${ }^{74}$ makes the regulation of GATT article XXIV more concrete and distinct, for the Understanding strengthens the procedural aspects and substantial amplifications of the rules. The compatibility of integration with GATT article XXIV should be examined by a Committee of Regional Trade Agreement (CRTA). ${ }^{75}$ The Understanding clarifies the procedures of "review," such as reports by a Working Party and recommendations by the Council for Trade in Goods. ${ }^{76}$ Particularly, the Understanding makes clear that WTO dispute settlement procedure may be invoked with respect to any matters arising from the application of GATT article XXIV. The General Agreement on Trade in Services (GATS) ${ }^{77}$ also allows economic integration, ${ }^{78}$ but requires that such integration "shall be designed to facilitate trade between the parties to the agreement and shall not in respect of any Member outside the agreement raise the overall level of barriers to trade in services within the respective sectors or subsectors compared to the level applicable prior to such an agreement." ${ }^{19}$

\section{a. Free Trade Areas}

A free-trade area, is an agreement in which members remove trade barriers among themselves but keep their separate national barriers against trade with

71. GATT 1947, supra note 41, at art. XXIV: 10.

72. "The contracting parties recognize the desirability of increasing freedom of trade by the development .... They also recognize that the purpose of a customs union or of a free-trade area should be to facilitate trade between the constituent territories and not to raise barriers to the trade of other contracting parties with such territories." Id. at art. XXIV: 4 (emphasis added) (the word "recognize" does not imply legal obligation).

73. See GATT 1947, supra note 41, art. I, XXIV: 4.

74. XXIV Understanding, supra note 41 , at 1161.

75. See Honkman \& Kostecki, supra note 43, at 352-55.

76. XXIV Understanding, supra note 41, at 1162, paras. 7-11.

77. General Agreement on Trade in Services (GATS), Apr. 15, 1994, in WTO Agreement, Annex 1B, 1869 U.N.T.S. 183 (1995).

78. Id. art. V: 1.

79. Id. art. V: 4. 
the outside world. In other words, an FTA is "a group of two or more customs territories in which the duties and other restrictive regulations of commerce ... are eliminated on substantially all the trade between the constituent territories in products originating in such territories." ${ }^{80}$ The European Free Trade Area (EFTA), which was formed in 1960, is an example of a typical FTA. ${ }^{81}$ In the 1950s, the United Kingdom was invited to participate in a series of conferences to build a plan for European integration, but it continued to favor an intergovernmental approach, such as EFTA, rather than a customs union. In point of fact, the EFTA is only an FTA marked by certain loose forms of economic cooperation. "The UK also sought to maintain its traditionally privileged relationship with the US." ${ }^{83}$ Another example of an FTA, which formally began at the start of 1994, is the North American Free Trade Area (NAFTA).

\section{b. Customs Unions}

In Customs Unions, members remove all trade barriers among themselves and adopt a common set of external barriers. A CU is an association of nations with duty free treatments for imports from members and a common level of external tariffs for imports from non-members. ${ }^{84}$ The European Economic Community (EEC), which existed from 1957 to 1992, was a CU that also included some other agreements. Another example of a CU is the MERCOSUR, which was formed by Argentina, Brazil, Paraguay, and Uruguay in $1991 .{ }^{85}$

\section{The Implications of the European Union Experience}

From the processes of European integration, three important empirical lessons should be learned. One is that, as an early goal of integration, a CU was preferred to an FTA. Initially the United Kingdom "had chosen to remain outside

80. GATT 1947, supra note 41, art. XXIV: 8(b).

81. See Pugel \& Lindert, supra note 16, at 214.

82. See The Stockholm Convention, Jan. 4, 1960, 370 U.N.T.S. 3 (establishing the European Free Trade Association, which includes seven nations: Austria, Denmark, Norway, Portugal, Sweden, Switzerland, and the U.K.).

83. BERMANN ET AL., supra note 20 , at 7.

84. See GATT 1947, supra note 41, art. XXIV: 8(a).

85. See Pugel \& Lindert, supra note 16, at 214. 
the EEC, and had proposed instead a looser and wider free trade area." ${ }^{\text {" It }}$ was not long before the United Kingdom changed its mind about becoming a member of the EEC. Another lesson is learned, as a result of the mid 1960s tension between France and the EEC, that a supranational model of regional integration was better than an intergovernmental model for the integration. ${ }^{87}$ In addition to the tension just mentioned, the Luxembourg Compromise ${ }^{88}$ had a negative effect on the direction and pace of the European integration over the next two decades. ${ }^{89}$ Finally, maintaining the some notion of sovereignty for states was necessary, even though Charles De Gaulle's notion of absolute sovereignty was not reasonable. This realization can be inferred from two facts. First, the major laws and institutions of European integration are a product of international agreements. In the processes of establishing treaties, including their signing and ratification, the members' governments were obliged to arrange their domestic system according to the integration process. ${ }^{90}$ Second, "on May 27, 1952, a European Defense Community (EDC) Treaty was signed by all six ECSC countries." ${ }^{91}$ Such a hasty agreement, however, was aborted because France refused to ratify the treaty. This fact implies that maintaining the military power of each sovereign state is the Achilles's heel in the integration process.

86. CRAig \& De BúrCa, supra note 19, at 14. See Bermann et al., supra note 20 , at 7.

87. The tension resulted from the change in the method of decision making at the Council of Ministers from a unanimous vote, which had been required and was preferred by France, to a qualified-majority vote. De Gaulle objected to the "federalist logic" of the change. See Craig \& DE BúrCA, supra note 19, at 12-14.

88. Paradoxically, the Luxembourg Agreement revealed the disagreement between France and the other five members. France urged unanimous agreement while the other five members accepted a majority vote on a proposal from the Commission. See id. at 13; 9 Bulletin of the Eur. Communities 3 (1966).

89. From the time of the Luxembourg Compromise until the adoption of the Single European Act in 1986, there was a move within the community from early supranationalism towards greater intergovernmentalism. CrAig \& de BúrCA, supra note 19, at 15. The Single European Act made the internal market integration more complete by revising the legislative process from unanimous voting to qualified majority voting. Single European ACT, June 29, 1987, O.J. (L 169) 6 (1987) [hereinafter SEA].

90. See Bermann et al., supra note 20 , at 22.

91. Id. at 6 . 


\section{An Economic Approach to the Definition}

There may be socio-cultural requirements that must be met before it is possible to move from one level of economic integration to the next, and that may limit the integration process. ${ }^{92}$ So, an FTA may be more easily established than a $\mathrm{CU}$ or another form of agreement that goes further. However, in this easier form of integration (FTA), which does not have a redistribution mechanism, a member could incur losses, even though the 'trade creation effect' are larger than the 'trade diversion effect' so that the region as a whole benefits. This potential problem causes some states to hesitate to integrate. The problem can be solved by the establishment of a redistribution instrument on a supranational basis, and by the creation of a "common market," which requires that the community, in addition to having a $\mathrm{CU}$, guarantee free movement of input factors, such as labor and capital, as well as goods and services. By removing restrictive rules concerning the migration of labor and capital, the EEC ${ }^{93}$ established a kind of common market in early 1960s. ${ }^{94}$ This guarantee of free movement of input factors is the best policy for the restructuring of industries following integration. A common market, of course, is a supranational structure.

\section{The Levels of Regional Integration}

A higher level of regional integration implies a higher level of economic interdependence, communication, cultural homogeneity, and the capacity to resolve conflicts. There are five levels of regionalization, ${ }^{95}$ and they are meaningful in evaluating the situation of Northeast Asia. The first level is a geographical unit, for instance Northeast Asia. The second level concerns trans-local or trans-

92. See JACKsON ET AL., supra note 5, at 211.

93. Article 2 of the EEC Treaty mandates the creation of a common market which pursues a harmonious and continuous development of economic activities with stability. Article 3 addresses the establishment of a common external tariff and commercial policy, the progressive elimination of barriers to the free movement of the principal factors of production, the creation of a common policy in agriculture, transport and competition areas, the coordination of economic and monetary policy, and the harmonization of the member laws for the proper functioning of the common market. Treaty Establishing the European Economic Community, Mar. 25, 1957, art. 3, 298 U.N.T.S. 11 [hereinafter EEC].

94. See Pugel \& Lindert, supra note 16, at 214.

95. See Hettne, supra note 11 , at 157-58. 
border relations of a socio-cultural and economic nature between human groups, namely non-state actors. The first and second levels of regionalization are prerequisites for a regional community. The third level is inter-governmental, organized cooperation in cultural, economic, or military areas. This level is the simplest basis for a regional community because the creation of a regional organization is a crucial step toward the community. ${ }^{96}$ The fourth level is regionally shared civil society, which has an organizational framework that promotes common socio-political and economic policies. In such a society, the existence of a shared cultural background throughout the region is important, but such a cultural background must also be continuously reaffirmed. ${ }^{97}$ This level means a genuine regional community. The fifth level is an acting global subject with a distinct identity and governmental structure.

\section{The Present Situation in Northeast Asia}

\section{a. The Limitation of the Asia-Pacific Economic Cooperation ${ }^{98}$}

In the Bogor Declaration of 1994, the APEC declared that it would liberalize trade and investment in the Asia-Pacific region by 2010 or 2020. It is currently implementing programs centered on the liberalization of trade and investment and the facilitation of economic technical cooperation. However, until now, with the advent of the APEC, there has been no real regional integration in Northeast Asia. Thus the characteristics of integration which are currently lacking in the Asia-Pacific are:

1) the institutional removal of domestic regulations to achieve a common market guaranteeing the free movement of capital, goods, services, and labor among member-states; 2) the develop-

96. See id. at 158 .

97. See id.

98. The Asia-Pacific Economic Cooperation (APEC) was established in 1989 in response to the growing interdependence among Asia-Pacific economies. APEC began as an informal dialogue group and has since become the regional forum, composed of twenty-one members, for promoting open trade and practical economic cooperation. See Asia-Pacific Economic Cooperation, About APEC, at http://www.apecsec.org.sg/apec/about_apec.html (last visited Mar. 18, 2004). 
ment of supranational organs ${ }^{99}$ as vehicles for decision-making (qualified majority voting) on measures necessary to ensure the functioning of that market; 3 ) a commitment to develop policies to reduce regional imbalances and enhance socio-economic integration within and between members of the community. ${ }^{100}$

This lack of integration is to be expected, because the APEC is not a force for true integration but a kind of loose intergovernmental form of co-operation. ${ }^{101}$

\section{b. The Japan-Korea Free Trade Agreement and the East Asia Free Trade Area}

Korea and Japan have promoted a Free Trade Agreement, namely the JKFTA. ${ }^{102}$ JKFTA could induce China, which was granted access to the WTO in 2001, to participate in a regional community. China has promoted a Free Trade Agreement in the form of ASEAN..$^{103}$ Also, the East Asian Free Trade Area (EAFTA), which would be composed of the ASEAN countries along with South Korea, China, and Japan, has been considered. ${ }^{104}$

The 1997 East Asian financial crisis produced painful confirmation that the region did not have a regional financial mechanism for the anticipation, prevention, and management of such a crisis. ${ }^{105}$ Presently, there is a strong movement

99. Though APEC has an emerging Secretariat in Singapore, currently there is not an institution functioning like the EU Commission. See Asia-Pacific Economic Cooperation, APEC Secretariat, at http://www.apecsec.org.sg/apec/about_apec/apec_secretariat.html (last visited Mar. 18, 2004).

100. Higgott, supra note 13 , at 47.

101. See id. at 44-45.

102. See JKFTA Joint Study, supra note 52.

103. On November 6, 2001, China and ASEAN agreed to establish an ASEAN-China FTA, the 7th ASEAN Summit, and the 5th ASEAN Plus Three Summit. See Bandar Seri Begawan, Press Statement By the Chairman of the 7th ASEAN Summit and the 5th ASEAN + 3 Summit (Nov. 5, 2001), available at http://www.aseansec.org/newdata/7thsummit_pr01.htm (last visited Mar. 18, 2004).

104. During the ASEAN Plus Three Summit, South Korea, China, and Japan agreed to establish a trilateral forum of economic ministers in an effort to strengthen economic cooperation among the three countries. The ASEAN Plus Three Summit decided to consider the establishment of the EAFTA. See id.

105. See Dobson, supra note 10, at 11. Before the crisis in East Asia, there were only two regional financial cooperations. The first, the APEC Finance Ministers, which is not truly regional, deals with social safety and capital flow. The second is the Executives' Meeting of East Asian and Pacific Central Banks (EMEAP) which was organized by Japan and Australia in the early 1990s. See id. 
toward monetary integration, ${ }^{106}$ and the ASEAN + 3 central bank governors and finance ministers have agreed to work out arrangements for currency swap among central banks. As a regional supplement system for the International Monetary Fund, an East Asian Monetary Fund (EAMF) has been proposed. ${ }^{107}$

According to the classification of levels of regional integration discussed above, the Northeast Asian region today has moved from the third level of regional integration to the forth level of regional integration. It is thus an opportune time to promote the NEAC.

\section{B. A Legal Definition of the NEAC: The Regional Community}

\section{Overview}

Based on the discussion thus far in this part, the NEAC, ideally should be a genuine regional community, and should embrace three characteristics: concerning economic integration, the NEAC should be supranational; concerning political integration, the NEAC should have an intergovernmental cooperation system like that of the intergovernmental conference (IGC) of the EU; concerning sovereignty, the members maintain their status as sovereign states, even though their sovereignty should be somewhat restricted. There, however, is a serious question concerning the distinction between economic integration and political integration, as it relates to the NEAC. The proper answer to that question can be gleaned from observing the EU integration. ${ }^{108}$ The extended scope of the

106. See generally Walden Bello, Inviting Another Catastrophe, 162 Far E. Econ. Rev. 42 (Aug. 12, 1999), available at http://www.feer.com/cgi-bin/HSE/HSE.cgi (discussing the Asian efforts toward economic reform and recovery). The Asian Monetary Fund (AMF) proposed by Japan just after the 1997 financial crisis was faced with objection by the U.S. and the IMF. AMF would have been capitalized to the tune of USD100 billion from the reserves of Japan, China and Taiwan, but the U.S. Treasury and the IMF were opposed to the idea because it would weaken the IMF. See id. 107. See Dobson, supra note 10, at 23; see also Ministry of Finance and Economy, Republic of Korea, at http://www.mofe.go.kr/mofe2/html/mainindex.php3 (last visited Mar. 18, 2004). Korea agreed to swap arrangements with Japan (USD 7 billion), China (USD 2 billion), Thailand (USD 1 billion).

108. The three pillars of the EU legal system are: Community; Common Foreign and Security Policy (CFSP); and Cooperation in Justice and Home Affairs (CJHA). In transition into the EU, the EC added the latter two pillars to the community pillar. See CRAIg \& DE BúRCA, supra note 19, at $30-46$. 
basic treaty, ${ }^{109}$ namely "the Community pillar," for establishing the NEAC can be classified as "economic integration," the other, which is the common foreign and security policy and the police and judicial cooperation in criminal matters, as "political integration."

\section{Maintaining the Members' Status as Sovereign States}

A regional community sometimes sends a single, representative delegation to discuss foreign affairs. For example, the EC participated in the Kennedy Round of negotiation, which successfully reduced tariffs and other trade barriers in 1967. ${ }^{110}$ The EU (Brussels) also performed multilateral negotiations of the Uruguay Round on behalf of the members of what was then the EC. ${ }^{111}$ In particular, it took part in the procedure of the Dispute Settlement Body (DSB) of the WTO as a single party. ${ }^{112}$ Moreover, the EU itself has a separate full membership in the Food and Agriculture Organization (FAO), which is one of the United Nations' specialized agencies. ${ }^{113}$ Thus while the EU members joined international organizations such as the United Nations. ${ }^{114}$ under their state names and performed unique activities within the organization, the members also acted

109. Under the Maastricht Treaty, policies regarding the free movement of persons, which includes visas, asylum, immigration, and judicial co-operation in civil matters previously covered by Justice and Home Affairs (JHA) were inserted into the body of the EC Treaty, namely "the Community pillar" by the Amsterdam treaty. See id. at 434.

110. See BermanN et al., supra note 20, at 8.

111. See Higgott, supra note 13 , at 54.

112. "Where the European Communities exercise their right to vote, they shall have a number of votes equal to the number of their member States which are Members of the WTO." WTO Agreement, supra note 41, at art. IX para. 1. "[The European Communities] shall become original Members of the WTO." Id. at art. XI para. 1.

113. The Conference may, by a two-thirds majority of the votes cast (provided that a majority of the members is present) decide to admit as a member any regional economic integration organization. See Constitution of the Food and Agriculture Organization (FAO) of the United Nations, Oct. 16, 1945, art. II para. 3, 12 U.S.T. 980, available at http://www.fao.org (last visited Mar. 18, 2004). To be eligible to apply for membership, a "regional economic integration organization must be one constituted by sovereign States, a majority of which are Member Nations of the Organization, and to which its Member States have transferred competence ... including the authority to make decisions binding on its Member States." Id. at para. 4.

114. In 1974, the U.N. General Assembly gave the EU (then the EC), by Resolution, such right to participate in the sessions and work of the General Assembly only in the capacity of observer. See G.A. Res. 3208, U.N. GAOR, 29th Sess., 2266th plen. mtg., at 2, U.N. Doc. A/L.734 (1974). 
collectively as a subject of international law by negotiating treaties in the name of the EU. Thus the EU members remain independent states even though their sovereignty is restricted by the EU. ${ }^{115}$ Even though there was a series of "historical, strategic and economic factors that [drove] and shaped this process, the states [remained its] core." 116 It should be the same with the NEAC. However, Northeast Asian countries have less experience with a supranational system and more with the role of governments in interstate bargaining. So, the early NEAC should gradually increase its control of members not only in the areas of economic integration and policy arrangement, but also in the political area.

\section{Substantial Socio-economic Integration}

The NEAC should be a kind of regional community. In order to guarantee the free flow of labor and capital and to get the full benefit of economies of scale, which derive from economic integration, a supranational control mechanism will be necessary. As the 1997 Asian financial crisis showed, there are many regional economic problems, which are difficult for only one state to solve. Furthermore, denationalization, which is increasing limitations on state sovereignty, is a typical characteristic of globalization. Thus if the NEAC, like the $\mathrm{EU}$, exercises its right as a regional community in international organizations, such as the WTO, and takes part in the procedures of international DSB as a single party, the results would be very efficient. ${ }^{117}$ Therefore, the NEAC should operate as a regional community, which means that there would be substantial integration of its members, accompanied by a partial restriction of the sovereignty of its members. In order to form a genuine regional community, labor forces, goods, capital, and services should be circulated without barriers between members, which would gradually lead to complete economic and social integration. Accordingly, in order to form the NEAC into a genuine regional community, it is necessary that it have the common market level of economic integration.

115. A member organization may exercise votes equal to the number of its members on matters within its competence. See Constitution of the FAO, supra note 113, at para. 10.

116. Higgott, supra note 13 , at 48.

117. For an overview of the WTO decision-making procedures, see WTO Agreement, supra note 41 , at art. IX. 


\section{Political Cooperation}

The relation between the NEAC and its members will maintain their sovereignty while it promotes political harmony and a common policy. For such a system of political cooperation, at first, there will need to be meetings of the foreign ministers of the members, an intergovernmental forum for cooperation in foreign policy, and the establishment of a permanent political secretariat, all of which were recommended by the EC's Davignon Report in $1970 .{ }^{118}$ Then, like the European Political Co-operation (EPC) system in 1973, a device for coordinating foreign policy by intergovernmental methods, ${ }^{119}$ the NEAC would speak with one voice in international organizations in which its members participated. Through such processes, just as the EPC has been upgraded to the Common Foreign and Security Policy (CFSP), ${ }^{120}$ a permanent Northeast Asian political organization could be developed. In the early stages of the NEAC, a supranational mechanism would not have much meaning, for there would not be arguments concerning qualified-majority voting and unanimous voting, because the NEAC would need the agreement of three key states, Korea, China, and Japan.

\section{The Economic Neeed to Establish the NEAC}

\section{A. Gains from the Product Market}

Increased gains from product markets result from removing internal tariffs. These gains are the fruits of internal, freer trade. Ricardo's principle of comparative advantage has been the theoretical basis for free trade since the nineteenth century, regardless of its unreasonable premises, which are "one input" and "constant opportunity cost." In the case of increasing opportunity cost, the parties of international trade get the gains, but perfect specialization on each comparative advantaged product would not take place. The gains from product markets can be explained by the trade creation effect, which refers to the expansion of trade with efficient suppliers inside a community. Economic integration, however, could result in losses because external tariffs remain. These losses can be explained

118. See Craig \& de Búrca, supra note 19, at 14-15.

119. See id. at 15; BERMANN ET AL., supra note 20, at 922-23.

120. See Geoffery Edwards, Common Foreign and Security Policy: Incrementalism in Action?, in International Law Aspects of the European Union 3 (Martti Koskenniemi ed., 1998). 
by the trade diversion effect, which refers to a shift in trade from efficient suppliers outside to inefficient suppliers inside the community. In short, the gains from economic integration are tied to the trade creation effect, and the losses are tied to the trade diversion effect. ${ }^{121}$ Therefore, the net welfare effect, that is, the trade creation gain minus the trade diversion loss, could be positive or negative. Thus, economic theory does not support economic integration in all circumstances. Still, as mentioned in Part I, the EU accrued some definite net gains from the integration, ${ }^{122}$ which would tend to confirm the following analysis. ${ }^{123}$

For the sake of analysis and simplification, the following assumptions should be made. First, all supply curves are perfectly elastic. All cars are a like product with same qualities in all respects. Second, the EU's tariff rate on foreign cars is a percent. And, before Spain's entry into the EU, its tariff rate on foreign cars was also á percent. Third, there are no tariffs for cars produced inside the EU. In Figure 1, the Korean car supply curve in the international free trade market is SK0. The Italian car supply curve in the international free trade market is SI0. After the levying of tariffs by Spain or by the EU on Korean cars, the supply curve shifts from SK0 to SK1. The car demand curve of Spain is Ds; In Spain, before levying tariffs, the price of Korean cars is USD 10,000, which is the cheapest. The next cheapest substitute is an Italian car, priced at USD 10,300. Finally, the prices include export or import cost.

In Figure 1, point $A$ indicates an imported car price and a quantity of cars in Spain before its entry into the EU, having maintained its own tariffs. At that time, the Spanish would buy only Korean cars at USD 11,000. So, Spain would import 1,000 Korean cars and no Italian cars. Point $A$ also indicates the price of Korean cars in the EU market, and point $B$ indicates the price of Italian cars in the EU market. After Spain joins the EU, it removes tariffs on imports from EU members, but not on imports from outside the EU. Thus, the Spanish no longer buy Korean cars; they buy only Italian cars. Point $C$ indicates the price of Korean cars in international market. If there were free trade without any tariffs, Korea

121. Harry G. Johnson, The Economic Theory of Custom Union, in Trading Blocs: Alternative Approaches to Analyzing Preferential Trade Agreements 127-28 (Jagdish Bhagwati et al. eds., 1999).

122. Pugel \& Lindert, supra note 16 , at 219-20.

123. See Jagdish Bhagwati \& Arvind Panagariya, Preferential Trading Area and MultilateralismStrangers, Friends, or Foes, in Trading Blocs: Alternative Approaches to Analyzing Preferential Trade Agreements, supra note 121, at 42-47; Pugel \& Lindert, supra note 16, at 216-18. 


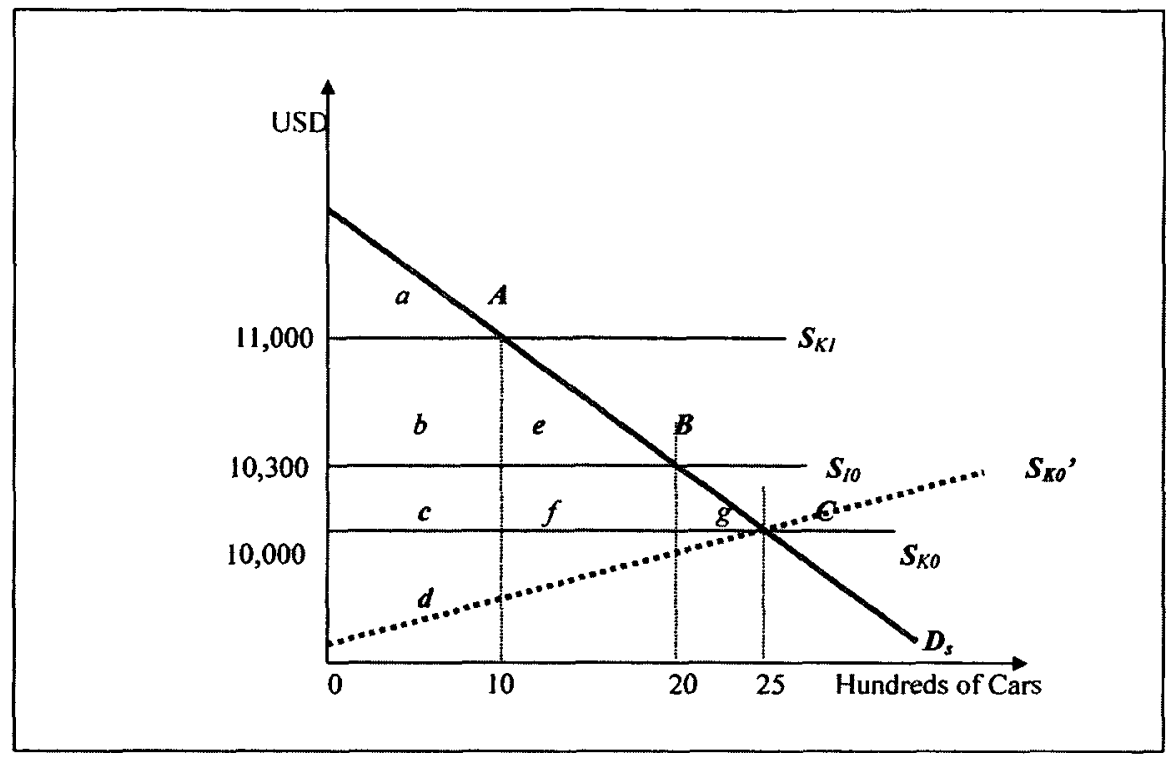

Figure 1: Hypothetical Market for Cars in Spain

could export 2,500 cars to Spain. The move from A to B creates 1,000 additional imports, which brings national welfare gains (area e), increasing consumers' surplus for Spain. However, it also diverts those 1,000 cars from the cheapest outside suppliers to the next cheapest suppliers of the members, bringing national welfare losses (area c), ${ }^{124}$ decreasing tariff revenues of Spain. (Before Spain's entry into the EU, area a was the consumers' surplus; area $b+c$ was tariff revenues; and area $\mathrm{e}+\mathrm{f}+\mathrm{g}$ was the "nation loss triangle" which is the net loss of consumers' surplus due to the levying of tariffs.) Thus, Trade Creation Effect (area e) $=1 / 2 \times(11,000-10,300) \times(2,000-1,000)=\$ 350,000$ : national welfare gains > Trade Diversion Effect (area c) $=(10,300-10,000) \times 1,000=\$ 300,000$ : national welfare losses.

The above analysis, however, should be modified because supplies are not perfectly elastic and because cost is not constant. In a more realistic model, the supply curves slope upward. In such a model, the trade diversion effect implies two additional consequences. First, the shift from suppliers outside the economic community to the inside suppliers makes the outside supply prices fall. It 
improves members' "terms of trade"125, which reduces the welfare losses from the trade diversion. So, the total welfare improvement of the economic community will occur at the expense of outsiders. Second, the shift from the suppliers outside the economic community to the inside suppliers causes the price of the inside supply to rise. Consequently, it reduces the consumer's surplus. However, it may increase the inside suppliers' surplus, which means that there is merely a shift of welfare from one member to another. ${ }^{126}$ Moreover, the net increase in product cost also will be distributed as wages, rent, interest, and profits inside the community. Given the social cost of unemployment, there is another gain in that product cost area. These two additional consequences of the trade diversion effect have two important implications. One is that the trade diversion effect is exaggerated in the above analysis. The other is that economic integration can bring a shift of welfare from one member to another as well as from outside to inside the community, which means that a member can incur losses, even though the trade creation effects are larger than the trade diversion effects, so that the economic community as a whole reaps welfare gains. Such a situation may make some states hesitant to cooperate with the economic integration. Therefore, a redistribution system, such as the EU's various structural funds and the CAP is necessary, even though the system would reduce the welfare of the economic community as a whole. ${ }^{127}$ The following hypothetical situations make the point clear.

Through all of these situations, among the outside suppliers of Spain, the Korean supplier is the most efficient, and the Italian supplier the next most efficient. The supplier gets a supplier's surplus at the rate of USD 1000/car. In Situation I, Spain keeps its own tariffs (USD 1,000/car) without joining the EU or another FTA. In this situation, Spain imports 1,000 cars from Korea, and 500 cars from Italy. As a result of such trade, each country gets a welfare increase: Spain gets USD 4.5 million, if the consumer's surplus is USD 3 million (tariff revenue equals 1.5 million, consumer's surplus equals 3 million); Korea gets

125. 4 The New Palgrave, A Dictionary of Economics 623-26 (John Eatwell et al. eds., 1987) (defining "terms of trade" as the ratio between the price of a country's export goods and the price of its import goods, namely the opportunity costs of export goods expressed by import goods).

126. See Johnson, supra note 121 , at $135-36$.

127. See Padoan, supra note 56, at 115 . In the necessity of redistribution systems, governments of members in the community tend to forge international institutions in order to meet various functional needs. 


\begin{tabular}{|l|l|}
\hline Situation 1 & Situation 2 \\
\hline Situation 3 & Situation 4 \\
\hline
\end{tabular}

Italy

Spain

(million USD)



Figure 2: Hypothetical Matrix

USD 1 million (supplier's surplus); Italy gets USD 0.5 million (supplier's surplus). In Situation II, Spain joins the EU, which does not have any redistribution system. The tariff rate of the EU is also USD 1,000/car. In this situation, given the trade creation and the trade diversion effects, Spain imports 400 cars from Korea, and 1600 cars from Italy. Through this trade, each country gets a welfare increase: Spain gets USD 4.0 million, if the consumer's surplus is USD 3.6 million (tariff revenue: 0.4 million; consumer's surplus: 3.6 million); Korea gets USD 0.4 million (supplier's surplus); Italy gets USD 1.6 million (supplier's surplus). In Situation III, a FTA is established between Spain and Korea. Spain keeps its own tariff, which is ten percent against any other country. In this situation, because of trade effects and efficiency, Spain imports 1,800 cars from Korea and 300 cars from Italy. Through such trade, each country gets a welfare increase: Spain gets USD 4.3 million if the consumer's surplus is USD 4.0 million (tariff revenue: 0.3 million; consumer's surplus: 4.0 million); Korea gets USD 1.8 million (supplier's surplus); Italy gets USD 0.3 million (supplier's surplus). In Situation IV, Spain joins the EU, which has a redistribution system. In this situation, the EU can distribute part of Italy's net gain (USD 1.1 million) to Spain. If the net gain is divided equally between Spain and Italy, the increase of welfare in the Situation II will be changed as follows; Spain gets USD 4.55 million; Korea gets USD 0.5 million; and Italy gets USD 1.05 million. These situations can be described through the matrix in Figure 2. Spain does not want the integration of 
Situation II, which is in the upper-right of the box in Figure 2. Spain, however, will certainly enter the EU, if such entry will give it an increase of welfare, as in Situation IV (see lower-right of the box in Figure 2).

Thus, analysis of the above hypothetical matrix reveals the necessity of establishing a regional system which can manage welfare distribution. ${ }^{128}$ Such a welfare distribution system can also develop policies that will reduce regional imbalances and enhance socio-economic integration among the members of the community.

\section{B. Gains from the Product Market ${ }^{129}$}

The H-O theory also supports free trade. Ricardian theory suggests that comparative advantage is derived from the difference in product costs, even though Ricardo does not explain the causes of the difference. The H-O theory does explain the difference of factor endowment and the difference in factor intensiveness as the cause of the difference in product costs. Accordingly, trade occurs as a result of "differences in the availability of factor inputs in different countries and differences in the proportions in which these factors are used in producing different products." ${ }^{130} \mathrm{H}$-O theory stresses factor proportion. In this theory, the factorprice equalization theorem implies that free trade will equalize not only product prices but also the prices of input factors between countries even if such factors cannot move between countries. ${ }^{131}$ Through free trade, laborers will eventually get the same wages in every country if they have homogeneous quality, even though laborers' migration between countries is not permitted. ${ }^{132}$ The equaliza-

128. The best form of regional integration is likely to exist when: the distributive means among members is comparatively stable; and members expect no change in this distribution. See Joseph M. Grieco, Systematic Sources of Variation in Regional Institutionalization in Western Europe, East Asia, and the Americas, in The Political Economy of Regionalism, supra note 26, at 174, 176. See generally Joseph M. Grieco, Anarchy and the Limits of Cooperation: A Realist Critique of the Newer Liberal Institutionalism, 42 INT'L ORG. 485, 485-95 (1988) (describing the conflict between realists and neo-liberal institutionalists and setting forth the beliefs of the respective schools of thought and the differences between them).

129. Gain from the product market and gain from the input market overlap in many respects.

130. Pugel \& Lindert, supra note 16 , at 61 .

131. "A shift in relative product prices brings an even more magnified response in factor prices." Id, at 67 .

132. In the real world, factor prices would not fully equalize among countries that constitute a FTA or a CU. The H-O theory implies that there appear to be tendencies toward equalization. See id. at 75 . 
tion of factor prices requires a process of specialization on abundant factors. Such specialization implies increased efficiency and economies of scale. Equalization of factor prices brings an optimum allocation of factors among countries on the whole. The increased efficiency, the economies of scale, and the optimum allocation of factors cause the rate of increasing opportunity cost to slow down, which means that the production-possibility curve becomes more elastic and approaches the linear curve that is the basis for Ricardo's principle of comparative advantage. In short, "the more a factor is specialized, or concentrated, into the production of exports, the more it stands to gain from trade." 133 In the $\mathrm{H}-\mathrm{O}$ approach, gains can be achieved through free trade without movement of factors, even though the theory requires the premises that each state has different plentiful factors and that these factors are homogenous.

Concerning an economic community, the H-O theory implies several things. First, it implies that the specialization on abundant factors, which means the rearranging of an industry, ${ }^{134}$ requires the sacrifice of sectors which use unselected factors. Which factors should be chosen? Who gets the fruit? These are very difficult questions to answer in a short time. Such a difficulty is one of the reasons that many barriers against free trade still remain, though every state knows that free trade is no longer a zero-sum game. Thus, "market integration [may] highlight disparities in regional wealth." 135 To ease such sacrifice, a path of retreat, or a kind of subsidy or traditional foreign aid program would be necessary. The EU has the redistribution mechanism of resources through the structural funds as well as Cohesion funds. ${ }^{136}$ The guarantee of free movement of factors would thus be one of the best policies. Second, economic integration may bring about more widespread and effective competition between firms and industries, and such competition would eliminate monopolistic distortions, ${ }^{137}$ whereas economies of scale, which are derived from the specialization on abundant factors, can result in monopoly. Thus, a policy of competition, such as that of the EU, is necessary to keep the fruit of economies of scale by means of the

133. Id. at 67.

134. There will be expansion in the export-oriented sector whereas there will be contraction in the import-competing sector. See id. at 73-75.

135. William J. Davey, European Integration: Reflections on Its Limits and Effects, 1 IND. J. GLoBAL Legal Stud. 185, 192 (1993).

136. See Padoan, supra note 56, at 115.

137. See Johnson, supra note 121 , at 138. 
regulation of monopoly. Third, if a community guarantees free movement factors as well as free trade, it more easily and directly benefits from the effect of $\mathrm{H}-\mathrm{O}$. In Figure 3, the area $(\mathrm{a}+\mathrm{b}+\mathrm{c}+\mathrm{d})$ describes the gain $(\mathrm{a}+\mathrm{b}$ : gain from product market, $c+d$ : gain from input market), which would be derived from the integration of markets between China and Japan. ${ }^{138} \mathrm{~A}$ high-wage country could gain (area c) by employing more immigrant labor from a low-wage country, and a low-wage country could gain (area d) by exporting more of its labor to employers in a high-wage country. Particularly considering the large differences in wages among prospective members of the NEAC, the countries would achieve the net gains from free movement of labor (the gains from free movement of labor minus the costs of removing barriers against free movement of labor). It means that efficiency in the inputs market also demands allowing inputs to move freely to the country where the inputs get the highest return, namely whose marginal product of inputs is highest, as free trade allows the high-price country to import the goods at a price less than what it would cost to produce the goods at home, and the low-price country to export the goods and receive a higher price than that of the domestic market.

In Figure 3, between the area ( + b: gain from product market) and the area $(c+d$ : gain from inputs market), which one is larger? It is arguable and depends on various conditions. A study shows that the area $(c+d)$ is larger than the area $(a+b)$, which means that the gains from removing barriers against the free movement of inputs, especially labor, could be great, and could far exceeding the gains from removing trade barriers. ${ }^{139}$ However, in the real world, the two sorts of gain, gain from product market and gain from input market, largely overlap each other. In the input market in Figure 3, the gap (w4-w2) implies the cost of movement or of homogenizing factors. The smaller the gap, the freer the movement of the factors or the more homogeneous the factors. ${ }^{140}$ The $\mathrm{H}$-O theory also

138. For the purposes of this analysis, assume that the NEAC is composed only of Japan and China.

139. According to Hamilton and Whalley, the gains from free movement of labor would more than double worldwide real income as well as improve the equality in income distribution. Bob Hamilton \& John Whalley, Efficiency and Distributional Implications of Global Restrictions on Labour Mobility, 14 J. Dev. Econ. 61, 70-74 (1984).

140. By the end of 1996, there were about 77,000 Chinese Koreans who wanted to make quick money by working in South Korea and more than half of them were illegal. In such a situation, some swindlers recruited laborers in China (Chinese-Korean community) and they charged a 


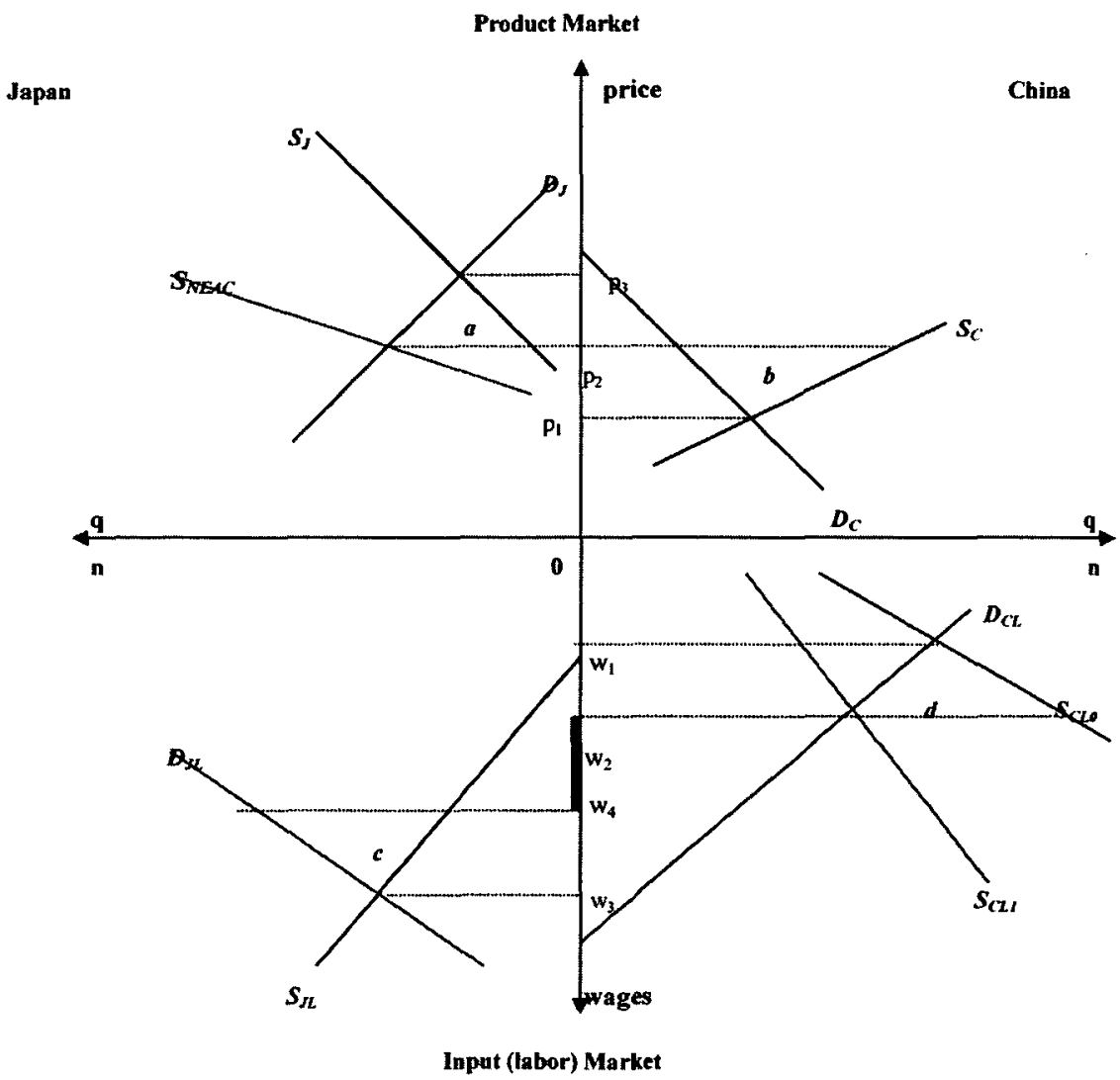

(In product market: $S_{C}$ : Chinese supply curve, $D_{C}$ : Chinese demand curve, $S_{j}$ : Japanese initial supply curve, $S_{N E A C}$ : Japanese supply curve after forming the NEAC, $D_{j}$ : Japanese demand curve, q: the product and consumption. / In input market: $D_{C z}$ : Chinese labor demand curve, $\boldsymbol{S}_{C L 0}$ : Chinese initial labor supply curve, $\boldsymbol{S}_{C L l}$ : Chinese labor supply curve after forming the NEAC, $D_{J L}$ : Japanese labor demand curve, $S_{J L}$ : Japanese labor demand curve, $n$ : the number of workers.)

Figure 3: Gains from Product and Input (Labor) Markets 
implies that the homogeneity of factors is a very important requirement for regional integration itself and for realizsing the effects of $\mathrm{H}-\mathrm{O}$. In fact, regional integration is a process of change from relative heterogeneity to increased social homogeneity.

\section{Advantages of Integration}

\section{Integrated Region v. Disintegrated Region}

In order to analyze and simplify the comparison between an integrated region and a disintegrated region, the following situation could be imagined. There are two regions, $\mathrm{A}$ and $\mathrm{B}$, in the world. The trade creation effect $=2$; the trade diversion effect $=-1$. This premise is based on the above analysis (Part III.A) and the empirical evidence of the EU (Part II). Moreover, regional integration provides a dynamic synergistic effect as well as opportunities derived from the enhancement of market access. ${ }^{141}$ The increase of a supplier's surplus inside a community $=1.5$. The decrease of the supplier's surplus outside the community $=-1.5$. In Figure 1, given that the supply curves (SK0') slope upward, the decrease of the supplier's surplus outside the community can be described as area (d). An argument can be made that it is always possible to form a regional community in such a way that the members are better off without any outside countries worse off. ${ }^{142}$ This argument, however, does not consider the fact that the economic integration in advance of time has market power, which is derived from improvement of the terms

commission and other fees. The commission and fees constituted a part of the "opportunity cost" for getting the higher wages. These "recruiters," however, disappeared as soon as they collected the money. The total loss to the Chinese-Korean community is estimated at about USD 30 million. Such losses imply a kind of social cost which is derived from the gap $\left(w_{4}-w_{2}\right)$. See Zhao, supra note 24, at 143.

141. See JSEPA Study Group, supra note 44, at $\S \S 1-2$. The dynamic synergy effects (e.g., accelerating the restructuring industries and industrial cooperation) brought about by increased competition and corporate alliance lead to the trade-creation effect once more. See Institute of Developing Economies: Japan External Trade Organization, Toward Closer Japan-Korea Economic Relations in the 21st Century (Summary Report) 19-22 (March 2000), available at http:// www.ide.go.jp (last visited Mar. 21, 2004).

142. According to this argument, the common external tariffs of the community make members trade with non-members under the same level of pre-integration. Another suggestion is that there is an incentive to integrate and extend the community until the world is integrated into one community. See Murray C. Kemp \& Henry Y. Wan, Jr., An Elementary Proposition Concerning the Formation of Customs Unions, 6 J. INT'L Econ. 95, 95-96 (1976). 


\begin{tabular}{|l|l|}
\hline A and B both form an economic community & A forms economic an community, B doesn't \\
\hline B forms an economic community, A doesn't & A and B together don't form an community \\
\hline
\end{tabular}

A region

(welfare)

B region

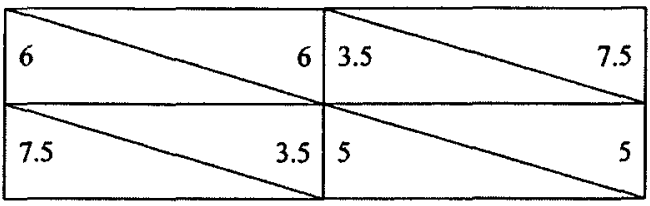

Figure 4: Hypothetical Matrix

of trade and efficiency. Furthermore, economic integration requires a process of difficult bargaining. ${ }^{143}$ Such an argument implies that an economic community can achieve a net gain by adjusting its external tariffs; the argument supports the analysis above. ${ }^{144}$ Another argument suggests that an economic community can impose an optimal external tariff, because it is bigger than its members and thus enjoys greater market power. ${ }^{145}$ It might seem that, in some cases, a monopoly company can reduce the price of its goods by using economies of scale. On the contrary, however, an economic community can be abused, even though GATT article XXIV regulates it. ${ }^{146}$ When both $A$ and $B$ together do not form an economic community, each region gets 5 as an initial gain.

143. See Stephan Haggard, The Political Economy of Regionalism in Asia and the Americas, in THE Political Economy of Regionalism, supra note 26, at 25-26.

144. See JACKson ET AL., supra note 5, at 466.

145. See Kenneth A. Froot \& David B. Yoffie, Trading Blocs and the Incentives to Protect: Implications for Japan and East Asia, in Regionalism and Rivalry: Japan and the UNited States in PAcific Asia 125, 136 (Jeffrey A. Frankel \& Miles Kahler eds., 1993).

146. Rules of origin and subsidization of industry could be used for the protectionist's purpose. The rules of origin in the EU are related to the industrial strategy. See Jeri Jensen-Moran, Choice at the Crossroads: Regionalism and Rules of Origin, 27 LAw \& PoL'y INT'L Bus. 981, 983-84 (1996); Organisation for Economic Co-operation and Development, Regional Trade Agreements and the Multilateral Trading System, TD/TC(2002)8/FINAL, at 142-43 paras. 472-74 (Nov. 20, 2002), at http://www.olis.oecd.org. With the competitive pressure on EU industries, the EU is likely to increase restrictive measures against imports from outside, which seem to be protectionist. See Davey, supra note 135, at 212-13. 

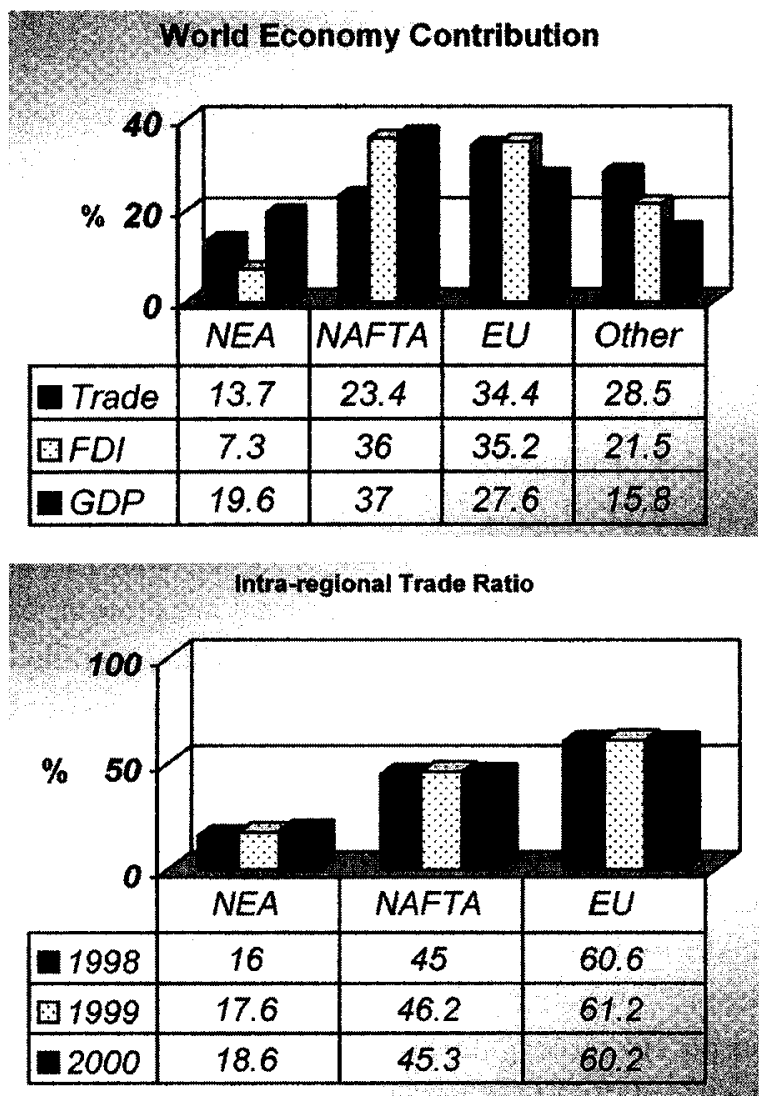

Figure 5: Major Region's Contribution to the Global Economy ${ }^{147}$

Figure 6: Intra-Regional Trade Ratio ${ }^{148}$

In Figure 4, I created a hypothetical matrix according to the above premises. It says that the upper-left of box (in the situation, A and B both form an economic community) is reasonable and fair.

147. The NEA includes South Korea, China (excluding Hong Kong and Macao), and Japan. FDI Statistics are from 1999. IMF, Direction of Trade Statistics, Yearbook 2001 (June) available at http://www.imf.org.

148. Intra-regional Trade Ratio = (Internal trade among states in the region / Total trade of states in the region) $¥ 100$. The table will show intra-regional trade and total trade in Northeast Asia, in NAFTA, and in EU (1998-2000). IMF, Direction of Trade Statistics (2000), available at http:// www.imf.org. 


\section{The NEAC $v$, the United States (NAFTA) or the European Union}

RTAs have flourished in the current world, particularly during the last decade. In particular, the advent of the NAFTA, which set the stage for a North American economic region, and the EU, forced the Northeast Asia countries to think of themselves as a region distinct from North America and Europe.

As Figure 5 shows, among the economically important regions, the Northeast Asian region is the only one that has not yet formed an integrated economic community.

The intra-regional trade ratios in Figure 6 illustrates two processes. First, the intra-regional trade ratio of Northeast Asia shows more of an increase in internal trade than in external trade. It also shows deepening trade regionalization in Northeast Asia, which is one of the requirements for regional integration. In order to acquire a more objective basis for trade regionalization, the so-called "double-relative," 149 which is the intra-regional trade ratio, taking into account the increasing weight of the Northeast Asian region in world trade, can be calculated. The double-relative of Northeast Asia in 1998 was 1.316; that in 2000 was 1.357 . It shows that trade regionalization increased distinctly from 1.316 to 1.357 in only two years. Second, the intra-regional trade ratios of the EU and NAFTA are very high. Especially in the EU, over 60 percent of trade is internal trade. This fact implies deepening competition or a narrowing trade market in the world, as well as a strong trade effect (net gains) from regional integration. ${ }^{150}$ Since the intra-regional trade ratio of the EU in 1980 was 42 percent, ${ }^{151}$ trade regionalization has been accomplished significantly.

149. Double-relative of Northeast Asia $(D R N E A)=$ Intra-regional trade ratio / Ratio of regional trade weight in world trade $=\{$ Intra-regional trade $(\mathrm{TNEA}) /$ Total trade of the region $(\mathrm{Tt})\} /\{\mathrm{To}-$ tal trade of the region (Tt) / World total trade (Tw). Jeffrey A. Frankel, Is Japan Creating a Yen Bloc in East Asia and the Pacific?, in Regionalism and Rivalry: Japan and the United States in Pacific Asia, supra note 145, at 54-56.

150. As a result of growing regional integration, intra-regional trade "has increased from $40 \%$ of total world trade in the period 1988-1992 to $42 \%$ in the period 1993-1997 ... Western Hemisphere trade agreements, such as NAFTA and MERCOSUR, ... showed more significant growth in the share of [intra-regional] trade, from 19\% in the period 1988-1992 to 27\% in the period 1993-1997." WTO Staff Paper, Preferential and Non-preferential Trade Flows in the World 1-2 (Sept. 1998), available at http://www.mofa.go.jp/region/asia-paci/singapore/sectionl.pdf (last visited Mar. 22, 2004); JSEPA Study Group, supra note 44, at §1-4.

151. See Frankel, supra note 149 , at 55. 
(million USD)

\begin{tabular}{|r|r|r|r|r|}
\hline & Korea & \multicolumn{1}{c|}{$\begin{array}{c}\text { China } \\
\text { (mainland) }\end{array}$} & $\begin{array}{c}\text { China (Hong } \\
\text { Kong) }\end{array}$ & \multicolumn{1}{c|}{ Japan } \\
\hline & & 23,754 & 10,146 & 15,143 \\
\hline & 15,508 & & 58,483 & 48,483 \\
\hline & 3,905 & 78,744 & & 10,745 \\
\hline
\end{tabular}

Table 1: 2002 Trade Matrix: Korea, China, and Japan ${ }^{152}$

(million USD)

\begin{tabular}{|c|c|r|r|r|r|}
\hline From & To & 1998 & 1999 & 2000 & 2001 \\
\hline Korea & China & 896 & 480 & 921 & 960 \\
\hline China & Korea & 8 & 27 & 76 & 70 \\
\hline Korea & Japan & 24 & 98 & 139 & 101 \\
\hline Japan & Korea & 504 & 1,750 & 2,448 & 772 \\
\hline Japan & China & 1,306 & 363 & 937 & 2,161 \\
\hline Taiwan & China & 2,035 & 1,253 & 2,607 & 2,784 \\
\hline Hong Kong & China & 6,985 & 7,758 & 7,791 & n.a. \\
\hline
\end{tabular}

Table 2: Major FDI Flowing in Northeast Asia ${ }^{153}$

In Table 1, the trade matrix of Northeast Asian countries ${ }^{154}$ shows vigorous trade in the region. In Table 2, the Foreign Direct Investment (FDI) flows in Northeast Asia, which indicate a steady increase in total new investment, show-

152. Korea International Trade Association, at http://kotis.kita.net/ (last visited Mar. 22, 2004).

153. The Export-Import Bank of Korea, Korea Government, Ministry of Commerce, Industry and Energy, at http:/www.mofat.go.kr; 2002 JETRO White Paper on International Trade and Investment (Summary) 18, at http://www.jetro.go.jp/it/e/pub/whitepaper/2002/1-a.html. There is a little difference between the Korean and the Japanese statistics.

154. Table 1 shows an imbalance in Korea-Japan trade (Korea's excess of imports), which has been a chronic problem between the two countries. After formation of JKFTA, a rapid increase of imports from Japan to Korea would create a greater trade imbalance than what currently exists. The trade imbalance would cause Korea to use more foreign currency; so, Korea would be a loser 
ing an increasing interdependence among Northeast Asian countries. ${ }^{155}$ In short, given rapid economic growth, intra-regional trade and investment rates in the Northeast Asia have increased greatly, which fosters regional economic interdependence. Therefore, in order to further trade and investment regionalization, and the resultant economic interdependence among the Northeast Asian countries, the NEAC should be established.

\section{The Necessity of Regional Financial Arrangements}

The Asian financial crisis of 1997, which revealed the weaknesses in entities of the international financial system such as the IMF and the World Bank, shows the necessity of regional financial arrangements. ${ }^{156}$ The existing international financial system, especially the IMF, failed to provide the countries in crisis with rapid aid at a time great need and with adequate prescriptions. ${ }^{157}$ Regional financial arrangements could bring the following benefits: reduction of vulnerability to

in the criterion of foreign exchange holdings. If both countries form an FTA, as is now being promoted, Korea's excess of imports would be deepened in spite of the gain from integration. In such a situation, the increase in Japanese exports to Korea (16.30\%) would surpass the increase of Korean exports (8.30\%) to increase trade surplus by $34.5 \%$. Institute of Developing Economies, supra note 141 , at 27 . Such high imports may cause Korea to hesitate in embracing the integration. The fundamental solution to this problem would be a "common market" that guarantees factor movement. Given the current situation, a more realistic answer would first take account of Japan's more preferential tariff rate and the proffered "reasonable time" requirement. GATT 1947, supra note 41, at art. I: 2, 4, art. XXIV:5. Second, it would extend the opportunity of Korean companies to Japanese public procurement. Id. at art. III: 8(a), art. IV.

155. Stock of intra-regional investment is also increasing. See, e.g., JETRO, White Paper on Foreign Direct Investment (Japan External Trade Organization), at tbls. 14 \& 19, at http/f www.jetro.go.jp/ it/e/pub/whitepaper/invest2000.pdf (last visited Mar. 22, 2004) (explaining that at the end of 1998, Japan's outward stock of direct investment to China, including Hong Kong, was USD 27.1 billion, and Japan's inward stock of direct investment from Chinese Taipei and Hong Kong was USD 2.1 billion).

156. See Dobson, supra note 10, at 20-21.

157. For example, the Korean situation was different from that of the others and was important because its economy is the eleventh largest in the world. At the time, the Korean economy was going well: real GDP grew at about 8 percent per year up to the crisis, just as it had in the 1980 s. Korea got into difficulties in mid-1997 because its newly licensed financial institutions had incurred short-term foreign debts. Since Korea's total foreign debt was only about 30 percent of GDP, which is the lowest level among developing countries, it was a temporary liquidity problem; so, the IMF should not have used its traditional policies, such as reduced government spending, higher taxes, and tight credit. See Martin Feldstein, Refocusing the IMF, 77 ForeIGN AfF. 20-33 (Mar./Apr. 1998); Pugel \& Lindert, supra note 16, at 609. 
capital flow and exchange rate instability; rapid aid according to a possibly bad regional situation; ${ }^{158}$ and assistance to its members through surveillance or through closer macroeconomic cooperation and technical support. Furthermore it can give early warnings of possible future crises and can work as self-help toward cooperative management of crises. ${ }^{159}$ To realize such benefits from monetary integration, members must have similar macroeconomic policy objectives.

\section{Socio-Political Requirements for NEAC Integration}

\section{A. The Issue}

Socio-politically, the NEAC integration needs to meet the general requirements ${ }^{160}$ of regional integration and the special requirements for NEAC. What are the requirements and how can the NEAC meet these requirements?

\section{B. General Requirements}

\section{Communications and Transactions}

Regional integration takes place in the sphere of communications and transactions among the prospective members, who hope that the communication and transactions will be kept open as much as possible. The increased institutionalization of the EU supports the functional argument that institutions in a region are more likely to form when the regional economic interactions increase. ${ }^{161}$ Unlike members of the EU, the Northeast Asian peoples did not develop considerable communication and transactions, even though there were only minimum diplomatic interchanges between governments or a small-scale unofficial relationship in the frontier areas. ${ }^{162}$ Furthermore, over the last half-century, the Northeast Asian countries had a complicated and hostile history. The region was wracked by World War II, the Korean War, and the all-embracing Cold War. For these

158. Dobson, supra note 10, at 19 ("[S]ubstantial infrastructure is required to strengthen the region's ability to intermediate savings more efficiently.”).

159. Id.

160. Lang, supra note 12 , at 50.

161. Mansfield \& Milner, supra note 26, at 8.

162. See generally Zhao, supra note 24, at 134 (detailing the relations between governments). 
reasons, the region has not been integrated up to the present. In contrast, today, as Table 1 shows, vigorous trade has taken place among the countries. Moreover, as Figure 6 shows, there has been deepening trade regionalization which means more internal trade and less external trade in the region. ${ }^{163}$ Similarly, FDI has also been increasingly regionalized. ${ }^{164}$ Table 2 notes the FDI flowing for totally new investment in Northeast Asia, and shows increasing interdependence among Northeast Asia countries. The leading economies, Japan, Taiwan, and South Korea, were major investors in China. Stock of direct investment is also increasing. ${ }^{165}$ In short, the region is becoming increasingly interdependent, measured in terms of both trade and capital flows. ${ }^{166}$ Such interdependence drives economic growth, and with trade and investment, cultural and personnel exchanges are also taking place among the Northeast Asian countries. Especially in 1998, Korea and Japan, by recognizing that the basis of cooperation lies in deep mutual understanding and exchange, agreed to promote cultural and personnel exchanges. ${ }^{167}$ Korea and Japan co-hosted successfully the 2002 FIFA World Cup which actively promoted exchanges in culture and sports. ${ }^{168}$

\section{Regional Identity}

Regional identity is a kind of psychological factor, a feeling of togetherness with respect to common geographical and historical matters, which forms the basis for regional integration. ${ }^{169}$ The question concerning regional identity is

163. See Asian Development Bank, Asian Development Outlook 61-62 (1992) (noting the rapid increase in intraregional trade in East Asia).

164. See Mitchell Bernard \& John Ravenhill, Beyond Product Cycles and Flying Geese: Regionalization, Hierarchy, and the Industrialization of East Asia, 47 WorLd PoL. 171, 179-83 (Jan. 1995) (noting that the wave of Japanese FDI that swept through the Northeast Asian region combined with the later wave of Taiwan, Korean, and Singaporean FDI, has fostered the growth of a large number of production networks throughout the region that have served to knit the region together).

165. See supra note 155 and accompanying text.

166. See Michel Oksenberg \& Elizabeth Economy, Shaping U.S.-China Relations: A LongTerm Strategy 45-46 (1997).

167. See Joint Declaration on a New R.O.K.-Japan Partnership for the 21 st Century, available at http://www.nyu.edu/globalbeat (Oct. 8, 1998) (last visited Feb. 27, 2004).

168. Id. See Official Site of The 2002 FIFA World Cup, 2002 FIFA World Cup: Korea Japan, at http://fifaworldcup.yahoo.com/02/en/ (last visited Mar. 2, 2004).

169. See Teija Tiilikanen, Does Europe Need a Common Identity? A Comment upon the Core Problems of the CFSP, in International Law Aspects of the European Union, supra note 120, at 21 (examining the EU from this perspective). 
whether the development of a regional identity, or at least a "shared awareness of region" among the prospective members, should be developing along with, or prior to regional integration. There are two attitudes concerning this question. One is that regional identity becomes an important factor for regional integration. ${ }^{170}$ The other attitude is that a regional integration needs to be extended to a wider, multi-actor dimension, and globalized circumstances. In pursuit of maximizing rational utility, the identity of region could be secondary. ${ }^{171}$ This attitude has become more persuasive with the rapid progress of information and communication technology, and argues that regional identity can arise "even in the absence of some geographical and historical indicators of expected 'regionness." "172 The APEC, for instance, may be a proof that regional identity is no longer an important factor for regional integration. Generally, however, the identity of a region is a factor in inter-regional relations, and regions can be cognitively identified in the same way that they can be historically or geographically determined. Of course, among the APEC members, there is as yet no combined objective comparable to that of the 'European Identity, ${ }^{, 73}$ which members can use for deepening the integration. Even in the EU, there is an identity crisis. ${ }^{174}$ Thus, identity would be the basis of interests. ${ }^{175}$

Even though the Chinese Character culture, Confucianism, and Mahayana Buddhism influenced all of Northeast Asia considerably and a recognition of "regionness" has gradually formed, there is a historical legacy of mistrust among Northeast Asian peoples. The Japanese from time to time have made the Koreans and the Chinese angry, and deepened their chagrin by the adulation of World War II criminals, ${ }^{176}$ the justification of past agression and colonization of

170. See Kupchan, supra note 28, at 211.

171. See Higgott, supra note 13 , at 46.

172. Id.

173. See Treaty on European Union, Feb. 7, 1992 O.J. (C 224) 1 art. B (Treaty of Maastrict) ("[T]lo assert its identity on the international scene, in particular through the implementation of a common foreign and security policy including the eventual framing of a common defence policy, which might in time lead to a common defence.") (emphasis added).

174. See Jürgen Habermas, Between Facts and Norms: Contributions to a Discourse Theory of Law and Democracy 445 (William Rehg trans., 1996) (1992); Tiilikanen, supra note 169, at 19 ("[T]here is no such identity in the European Union and that this [sic] is the main obstacle to the construction of a real common foreign and security policy.").

175. See id. at 21; East Asia Vision Group Report 2001, supra note 31, at 8, para. 13.

176. See Rebecca MacKinnon, Japan's Prime Minister Visits a War Shrine, Aug. 13, 2001, at http:// www.cnn.com/ (describing China and Korea's angry reactions to Japanese Prime Minister Koizumito's visit to Yasukuni shrine, which commemorates convicted World War II criminals). 
neighboring countries, and distortion of history textbooks. ${ }^{177}$ Japan needs to understand the nature of the region, where remembrance of the past is stronger than in the West, and where ethics and feelings may be considered more important than economic benefits. For example, Korea, who has been continuously invaded by neighboring powers in the past, has a traditional suspicion of external powers. ${ }^{178}$ Thus, many Koreans seem to believe that Japan is a threat to Korea, ${ }^{179}$ and that the Japanese do not want Korea to be prosperous. ${ }^{180}$ In order for Northeast Asian countries to have a feeling of togetherness, self-confidence and an understanding of each other are the most necessary factors in the NEAC integration. "Identity is real, but is made and remade." ${ }^{181}$

\section{A Certain Level of Economic Development}

The level of economic development of prospective members is a significant factor, because the leveling of differences among the members principally increases integration costs, which can be compensated by the various funds. Within the EU, problems have arisen because of the varying development levels among the members. ${ }^{182}$ The JSEPA could easily enable Japan and Singapore to develop new opportunities for moving ahead from the rapid development of information and communications technology, because both countries are among the more developed economies in Asia, and are at similar levels of economic development. ${ }^{183}$ The development gap, however, does not really jeopardize the

177. See Japan Stands Firm Over History Textbook, May 17, 2001, at http://www.cnn.com/ ("Japan's firm stance on not revising its history textbooks continues to annoy China and South Korea, which maintain that the facts on wartime atrocities should be corrected.").

178. See Donald P. Gregg, The Two Koreas and Northeast Asia in the Post-Cold War Era, in The Two Koreas and the United States, supra note 24, at 169, 172.

179. See Okonogi, supra note 55, at 129 ("[T]here have been instances such as the 1991-92 R.O.K. Defense White Paper in which Japan was treated as a hypothetical enemy.").

180. For example, many Koreans believe that the Japanese would be against unification of the two Koreas because they do not like the possibility of a new threat. In reality, most Japanese people do not have such concrete thoughts about the issue. If they do, it would be a vague apprehension about the immense uncertainty in the process of unification. See id. at 127-29.

181. Davydd J. Greenwood, Cultural Identities and Global Political Economy from an Anthropological Vantage Point, 1 IND. J. Global Leg. Stud. 101, 115 (1993).

182. Davey, supra note 135 , at 200-01.

183. The 1998 GNP per capita of Japan ranked fifth; that of Singapore ranked sixth in the world. ISEPA Study Group, supra note 44. 
process of integration if there is strong regional identity and a necessity of integration, according to which the more developed country assumes its status as a net contributor. ${ }^{184}$

\section{Institution Building ${ }^{185}$}

In order to form a regional integration, there must be powerful civil institutions that push the integration as one of their goals. ${ }^{186}$ Concerning regional integration, institutions promotes economic integration and put into effect the integrating rules which are adopted by basic treaty in the processes of integration. ${ }^{187}$ Institution building creates a way of dependence among members and a vested interest in integration. Institutions also provide a kind of social cement that mitigates self-interest and opportunism. ${ }^{188}$ Institutional building within a region depends on the preferences and bargaining power of members. ${ }^{189}$ "The lack of a regional mechanism for intergovernmental dialogue and cooperation has been a distinctive feature of East Asian international relations." ${ }^{190}$

\section{External Economic and Political Environment}

The WTO-centered MFN trade liberalization could be evaluated as a better way than the $\mathrm{NEAC},{ }^{191}$ because a regional economic community has an innate exclusiveness which may conflict with the interests of non-members. ${ }^{192}$ However,

184. See Davey, supra note 135, at 200-01. In 1999, in Berlin, the EU Council decided to make a fund to support ISPA, SAPARD, and new members that would join the EU during 2002-2006. Enormous investment is required for the applicant countries, such as Eastern European countries. See Council Regulation $1267 / 99$ art. 3, 1999 O.J. (L. 161); Council Regulation 1268/1999 art. 8, 1999 O.J. (L. 161).

185. See discussion on institutionalization infra part IV.D.2.

186. See Davey, supra note 135, at 198-99.

187. See id.

188. See Douglass C. North, Structure and Change in Economic History 36-37 (1981).

189. See Haggard, supra note 143, at 31-48.

190. Enst Asia, supra note 1, at 7.

191. Bhagwati \& Panagariya, supra note 123 , at 35.

192. See Cho, supra note 33, at 420. Forming RTAs in which tariffs do not satisfy MFN may undermine a multilateral system. Kyle Bagwell \& Robert W. Staiger, Will Preferential Agreements Undermine the Multilateral Trading System?, in Trading Blocs: Alternative Approaches to Analyzing Preferential Trade Agreements, supra note 121, at 505-21. 
non-hegemonic regional integration, especially that among developing countries, can be considered more favorably. ${ }^{193}$ Thus, it is important that the NEAC should not only employ no protectionism, but also make the outside neighboring countries understand the necessity of its integration. In the globalized world, where one state's or one region's matter can be directly related to conflicts involving the interests of other states or regions, the assent of related countries is essential. Support from major powers, especially the United States, Russia, ${ }^{194}$ and the EU is important. Through the process of persuasion, countries outside the NEAC region can be convinced that the NEAC integration is not intended to exclude them, but instead to be useful to them.

\section{Geographic Proximity}

Regionalism generally refers to an uneven concentration of economic flow or the arrangement of foreign economic policies among a group of countries in close geographic proximity. ${ }^{195}$ There is also an attitude that distance between states and the transport costs create a trade bloc. ${ }^{196}$ Contrary to the definitions that geographic proximity is an element in regional integration, there also are definitions of regionalism formulated in non-geographic terms. For example, regionalism may be defined as a group of countries collectively relying on one member country's currency, which constitutes a currency region, although countries that share common socio-cultural backgrounds without geographic proximity could also be considered regional members. ${ }^{197}$ Globalization, with its

193. Bhagwati \& Panagariya, supra note 123, at 33-35.

194. Even if the influence of Russia has been reduced since the end of the Cold War, Russia is still a powerful nation. Furthermore, with its abundant resources, Russia would continue to play a certain role in Northeast Asia. Due to its growing concern about Northeast Asia, Russia attempted to rebuild relations with North Korea by the Treaty of Friendship. Herbert J. Ellison, Russia, Korea, and Northeast Asia, in Korea's Future and the Great Powers 169-70, 179-80 (Nicholas Eberstadt and Richard J. Ellings eds., 2001).

195. See Mansfield \& Milner, supra note 26, at 3-4.

196. See Jeffrey A. Frankel, Regional Trading Blocs in the World Economy System 30 (1997).

197. See Benjamin J. Cohen, The Political Economy of Currency Regions, in Pourtical Economy of Regionalism, supra note 26, at 50-51. 
rapid progress in information and communication technology, ${ }^{198}$ certainly dilutes the effects of geographic proximity. The Internet has contributed significantly to a borderless global economy by making physical distance often irrelevant. Some analyses of regionalism focus on the wide variety of preferential economic arrangements negotiated by states, for instance, the U.S.-Israeli Free Trade Area, which does not involve geographic proximity. ${ }^{199}$ However, the definitions that do not emphasize geographic proximity are mostly concerned with exceptional cases which are based on alternative elements, such as the heritage of colonial relations or the relation of strong military allies. The EU has integrated geographically proximate countries, and though the United Kingdom has a close historical relation with the United States, it is now a member of the EU, not NAFTA. Similarly, the United States is not a member of the EU, ${ }^{200}$ but it has much in common with European culture. Japan is not a member of NAFTA, but it is one of the biggest trade partners of NAFTA. Such facts show that geographic proximity is still an important factor for regional integration. Moreover, geographic proximity is the essence of regional identity, especially in Northeast Asia, because most of the peoples there were natives who have rooted in a given place for five thousand years. The APEC-centered Asia-Pacific is sometimes considered a new kind of region because it cannot be seen as a geographically proximate entity. Unlike Northeast Asia, however, Asia-Pacific has no shared history or common culture which forms a true regional unit. ${ }^{201}$

198. Neo-liberalism associated with globalization and the resulting collapse of time and space in international economic transactions challenges many of the traditional values and practices of corporate governance. See Suzanne Berger, Introduction, in National Diversity and Global CapiTALISM 14 (Suzanne Berger \& Ronald Dore eds., 1996); JSEPA Study Group, supra note 44.

199. See generally Edward D. Mansfield \& Rachel Bronson, The Political Economy of Major-Power Trade Flows, in Political Economy of Regionalism, supra note 26, at 188, 189-90.

200. See TEU, supra note 21, at art. 49 (restricting application for EU membership to "[a]ny European State which respects the principles set out in Article (6)(1)").

201. Under the influence of the United States, the APEC might be considered "another attempt to ensure continued U.S. and Western hegemony of the non-Western world." Chandra Muzaffar, Letter, Concern about APEC's Direction, Sydney Morning Herald, December 8, 1993, at 12. 


\section{Democracy and a Market-Oriented Economy}

The EU is founded on the common principles of liberty, democracy, ${ }^{202}$ respect for human rights and fundamental freedoms, and the rule of law. ${ }^{203}$ Any European State that applies for membership in the EU is required to respect these principles. ${ }^{204}$ The EU also requires the existence of a market-oriented economy as well as the capacity to cope with competitive pressure and market forces within the Union. ${ }^{205}$

Such requirements are also reasonable, on the whole, for the NEAC integration, and they would entail China's and North Korea's adoption of a marketoriented and democratic reforms. China is on the path of transition to such a market-oriented economy because of its early decisions in economic policy. As a result, China's WTO participation will be a reality sooner, because China shall be able to comply with the various obligations in the WTO rule. ${ }^{206}$ Concerning the democratization requirement, especially the guarantee of human rights, China's present situation is still dark, notwithstanding partial reform. First of all, China should forbid routine torture and do away with cruelty ${ }^{207}$ in criminal

202. The 1994 Summit of the Americas for establishing FTAA also emphasizes preserving and strengthening democracies. See Miami Summit's Declaration of Principles and Plan of Action, December 11, 1994, 34 1.L.M. 810,815. Cuba is the only country which has been excluded from the Summit of the Americas. See generally id. at 810 (restricting participation in the Summit of the Americas to democratic societies).

203. See TEU, supra note 21 , at art. $6(1)$.

204. See id. at arts. $6(1), 49$.

205. The 1993 Copenhagen European Council, concerned with the accession of countries in Central and Eastern Europe, agreed on the following requirements: stability of institutions guaranteeing democracy; the rule of law; human rights and respect for and protection of minorities; and the existence of a functioning market-oriented economy. See Copenhagen European Council, 26 Bull. of the Eur. Communities nos. 6, 7 (June 1993).

206. See generally WTO Agreement, supra note 41, art. XII (declaring that "any State ... possessing "full autonomy in the conduct of its external commercial relations ... may accede" to the WTO).

207. Under Chinese criminal law, more than sixty crimes, many of them nonviolent, can be punished by death. See China: 'Striking Harder' than Ever Before, Amnesty International Online, at http://web.amnesty.org/ai.nsf/Index/ASA170222001 (visited on Feb. 27, 2004). The crimes include bribery, pimping, embezzlement, tax fraud, stealing petrol, and the selling of harmful foodstuffs. See id. In recent years, China has sentenced to death and executed thousands of people. See id. 
law and in practice. ${ }^{208}$ As for North Korea, it will be not likely be qualified in both adopting a market-oriented economy and democratizing, as long as the present regime exists. This situation, then, implies two things. First, in the early stage of NEAC integration, it will be hard to apply a strict democratization requirement like that of the EU. Second, reform in North Korea and the unification of the two Koreas should not be considered pre-requisites for early NEAC integration, but a byproduct of the process of integration itself. The unification of two Koreas, which can be an absorptive unification or any other kind, would be the same process for North Korea's accession to the NEAC.

\section{Special Requirements of the $N E A C$}

\section{Clearance of Post-War Claims}

Quite a number of innocent people from China, Korea, and other East Asian countries were sacrificed in the process of the Japanese invasion in World War II. When the War was over, post-war problems were settled through peace treaties with the Allies and joint treaties with neighboring countries (though not yet with North Korea), for the sake of formality. However, even though postwar problems were settled at the state level, and in spite of Japan's assertion that all necessary post-war problems have been legally settled, ${ }^{209}$ there remain a lot of tort claims between Japan and its individual victims including soldiers, slave laborers, ${ }^{210}$ and sex slaves ${ }^{211}$ conscripted from Korea and China. Japan should settle these problems as soon as possible.

208. See generally Report of the Committee against Torture, U.N. GAOR 51st Sess., Supp. No. 44, paras. 138-50, U.N. Doc. A/51/44 (1996) (noting the widespread practice of torture in China and recommending solutions to deal with the problem).

209. In 2001, a Japanese court ruled against compensating a group of former South Korean sex slaves and soldiers who were forced into service by Japan's army during World War II, relying in part on a 1965 treaty establishing diplomatic ties between Japan and South Korea. See Japan Will Not Pay Out Korean Sex Slaves, CNN Online, Mar. 26, 2001, available at http:/www.cnn.com/ (last visited Feb. 27, 2004).

210. See Donald MacIntyre, Fighting for Wartime Retribution, Time Asia, Jan. 17, 2000, available at http://www.time.com/ (last visited Feb. 27, 2004).

211. As many as 200,000 women, mostly Koreans, were abducted as sex slaves for Japanese soldiers during World War II. See Japan Will Not Pay Out, supra note 209. 


\section{Peace and Stability in Northeast Asia}

Today, the major uncertainty in Northeast Asia lies in the Korean peninsula, in which the two Koreas still exist with the prospect of unification in the near future. There are two causes of uncertainty. One is the possibility of North Korea's nuclear development and its missile tests and exports which influence regional security beyond the Korean Peninsula itself. ${ }^{212}$ The other is the possibility of rapid collapse of North Korea which would bring a jumble with a large inflow of refugees. The burdens on the region derived from the uncertainty would be immense. ${ }^{213}$ Even though no one can predict how and under what conditions Korean unification will take place, a so-called "soft landing" is obviously desirable. ${ }^{214} \mathrm{~A}$ soft landing means that North Korea will undergo some economic and political reform with assistance from South Korea and international society. Thus, a soft landing, which is now described as the "Sunshine" policy of South Korea, would be the least costly way to guarantee peace and stability in the Korean peninsula. The Sunshine policy would also promote a new security framework on the Korean peninsula that would consolidate peace and stability in the region by engaging North Korea in a serious dialogue so as to remove its threat. ${ }^{215}$ However, such a policy has not brought visible results except for the

212. See Hisashi Owada, An East Asian Security Order for a Globalizing World, in East Asia, supra note 1, at 80. In November 2001, U.S. President George W. Bush urged North Korea to allow inspections for weapons of mass destruction if it wanted better relations with the United States. North Korea is believed to have "5000 tons of chemical weapons and an unknown stockpile of germ warfare agents, including anthrax and smallpox." N. Korea Slams Call for Arms Inspections, CNN Online, Nov. 29, 2001, available at http:/www.cnn.com/ (last visited on Feb. 27, 2004).

213. The world began to realize that peace and security had become a universal or global responsibility. After the Cold War, such recognition has been reinforced by a number of causes, including global threats to peace and security, the global challenges of underdevelopment, poverty, mass migration, and global treatment of the environment. See Jost Delbrück, Globaliztion of Law, Politics, and Markets-Implications for Domestic Law: A European Perspective, 1 Ind. J. Global Legal Stud. 9, 13 (1993). Among the causes listed above, North Korea poses a problem for the Northeast Asian region and the world with respect to peace and security, underdevelopment, poverty, and the threat of mass migration.

214. See Robert A. Scalapino, Korea and the United States: Looking to the Twenty-first Century, in The Two Koreas and the United States, supra note 24, at 274-77.

215. See Owada, supra note 212 , at 80. 
first South and North summit and a few reunions of separated families. It may be "unwise to abandon all 'sticks' and rely wholly upon 'carrots'." 216

Territorial disputes, such as the Dok-do Conflict between Korea and Japan and the Joado Conflict between China and Japan, are restrained under the present situation. ${ }^{217}$

Peace and security in Northeast Asia is not only an indispensabl requirements for the NEAC integration but also one of the goals of that integration.

\section{A Plausible Way to Meet the Requirements}

\section{Confidence Building and Harmonization}

Since European countries have shared similar culture with languages based on the same Latin roots, they could move faster toward a community. In contrast, lack of such linguistic homogeneity in Northeast Asia hinders cooperation among the countries. Furthermore, their approaches to co-operation are based on confidence-building, peer pressure, and trust rather than formal agreements and institutions. ${ }^{218}$

To achieve such homogeneity and confidence among Korea, China, and Japan, they need: the support of less developed regions; human capital development; the removal of obstacles in travel; and the strengthening of infrastructure for development in information and communications technology, and improvement in transportation. Such work could be done at both the non-governmental and governmental level.

Supporting less-developed regions, like North Korea, implies two things. First it implies a reduction of the development gap among different countries and

216. Scalapino, supra note 214, at 280. In September 2001, the South Korean Unification Minister resigned following the passing of a no-confidence motion in the parliament because he was in charge of the policy towards the North and had come under increased attack in South Korea for being 'too soft' on the communist North. See No-Confidence Vote Rains on Korea 'Sunshine' Policy, CNN Online, Sept. 3, 2001, available at http://www.cnn.com/ (last visited Mar. 7, 2004).

217. Some Koreans maintained that the Yanbian Korean Minority Autonomous Region of China, whose border was obscure before Japanese rule in the Korean peninsula (1905-1945), was a part of Korean territory. Concerning this problem, China protested to Korea in 1995. See Zhao, supra note 24 , at 143.

218. See Higgott, supra note 13, at 47. 
the management of instability, such as the EU's various structural funds. ${ }^{219}$ Such a - program could be a carrot for inducing reform in less developed counties. Like the EU's CAP ${ }^{220}$ or assistance to disadvantaged regions, ${ }^{221}$ supporting less developed regions should continue even after integration has begun. A civilian or an international cooperative system to develop Russia, China, and North Korea, like that of the UNDP-TRADP ${ }^{222}$ would be important in that respect, as would be economic cooperation between South and North Korea. ${ }^{223}$ The Korean Peninsula Energy Development Organization, an organization similar to some early European institutions, is expected to manage instability. ${ }^{224}$ The unification of the two Koreas could be aided by the regional integration as the EU is about to incorporate former

219. See Instrument for Structural Polices for Pre-Accession (ISPA), Council Regulation 1267/ 99, art. 6-7, 1999 O.J. (L 161) 73-86; see also The Special Accession Programme for Agriculture and Rural Development (SAPARD), Council Regulation 1268/99, 1999 O.J. (L 161) 87-93 (supporting pre-accession measures for agriculture and rural development in the applicant countries of central and eastern Europe in the pre-accession period).

220. See generally BermanN ET AL., supra note 20, at 1063-80.

221. See GATT 1947, supra note 41, art. XVI; see also WTO Agreement on Subsidies and Countervailing Measures, art 8.2 (b), available at www.ia.ita.doc.gov/; East Asia Vision Group Report, supra note 31 , at 22 para. 90.

222. Since 1991, the Tumen River Area Development Program (TRADP) has aimed at providing a basis for multilateral cooperation among the countries in Northeast Asia by developing the Tumen River area into an international hub of transportation, processing, and manufacturing under the development strategy of "gradual harmonization." The project is managed by the UNDP, while the two Koreas, China, Russia, and Mongolia are participating as full members and Japan, Finland, and Canada are taking part as observers. See Tumen River Area Development Programme, at http//www.undp.org/ (last visited Mar. 7, 2004) (UNDP report on the TRADP program).

223. Besides thousands of tons of food and artificial fertilizer aid, the trade volume between the two Koreas was USD 425 million in 2000. Thirty-nine South Korean companies promote interKorean joint ventures. The Mt. Kumgang tourism project consisted of more than four hundred thousand South Koreans during the period from 1998 to 2001, which resulted in HyunDai, the hosting South Korean company, to pay about USD four hundred million to North Korea as the admission fee. See Ministry of Unification, Inter-Korean Relations (Jan. 2001), available at http:// www.unikorea.go.kr (last visited Mar. 7, 2004).

224. In exchange for North Korea's freezing and eventually dismantling its nuclear program, The Korean Peninsula Energy Development Organization (KEDO) is supplying North Korea with two proliferation water reactor units and heavy fuel oil for heating and electricity. See generally Kedo: Promoting Peace and Stability on the Korean Peninsula and Beyond, available at http:// www.kedo.org/ (last visited Mar. 7, 2004). 
Communist countries. The goal of developing human capital for NEAC integration is cultivating regional leaders ${ }^{225}$ and increasing competitive power. Joint training of young, elite students from the region would help to resolve the lack of regional homogeneity. ${ }^{226}$ Through such training, prospective leaders would achieve mutual understanding and closer relationships. ${ }^{227}$ Developing human capital provides the key competitive advantage in a knowledge-based economy. ${ }^{228}$ The qualifications and standards for professionals should be universal, with common recognition and administration of the licenses of lawyers and doctors.

The flow of human capital with goods, service, money, and information, which will create a larger flow of culture and technology, bring about better harmonization within NEAC region, and provide a strong platform for NEAC integration. A visa-free agreement among Korea, China, and Japan would reduce obstacles to travel. ${ }^{229}$ Information and communications technology has transformed the global economy and their infrastructure and the skillful use of information have become cornerstones of economic growth in the Internet economy. ${ }^{230}$ In fact, the infrastructure for information technology, like the railroads of Europe in the nineteenth century, connects various regions and world more closely. Also, in order to increase the flow of men and goods in the region, infrastructure for transportation is important. ${ }^{231}$

225. As the ECSC was inspired by Jean Monnet, the French proponent of European integration, regional integration is influenced by the will of leaders. See Bermann et al., supra note 20, at 1063-80.

226. See East Asia Vision Group Report, supra note 31, at 24 para. 98. The Transnational Law and Business University is an example of an institution that increases regional academic interaction and exchange. See Transnational Law and Business University, at http:/www.tlbu.ac.kr (last visited Mar. 7, 2004).

227. Discussions have taken place between Japan and Singapore on harmonizing university curricula and exchanging professors and students. See, e.g., JSEPA Study Group, supra note 44, at $\S \S 2-36,2-37$.

228. See id. at $\$ 2-35$.

229. Korea and Japan agreed on temporary visa-free travel during the FIFA 2002 World Cup, which was co-hosted by both countries. With entry to the WTO, China enhanced a measure for freer foreign travel.

230. See JSEPA Study Group, supra note 44, at $\$ 1-4$.

231. The two Koreas are working on connecting a railway and a highway between Munsan and Kaesong. The construction is taking place within the Demilitarized Zone. Economically, the transportation link will reduce shipping costs between the two Koreas, and once the inter-Korean railway is linked to the Trans-Siberian or Trans-China Railway, a Northeast Asian railway network would be activated. See http://www.unikorea.go.kr (last visited Nov. 24, 2001). 


\section{Institutionalization}

In order to build a basic community system, there would first need to be a multilateral cooperation framework, such as the APEC and the ARF, so that the representatives of the members may have a permanent channel for exchanging their views and build up respect and confidence among them. Southeast Asia has had regional networks, such as the ASEAN, but in Northeast Asia, with the United States as a stabilizer, Korea, China, and Japan have depended on mostly bilateral relationships.

In November 2001, Korea, China, and Japan agreed to establish a trilateral forum of economic ministers to strengthen economic cooperation among them. ${ }^{232}$ Through this forum, the three countries promoted the possible cooperation by constant effort. This trilateral forum would be a stepping-stone for NEAC economic institution building. The more important thing is that the three states should build supranational institutions concerning economic integration as soon as possible, as the High Authority of the ESCS had some supranational power even its early stage. ${ }^{233}$ The economic institutions would also deal with the financial arrangements

The security integration model embodied by NATO and the EU, which is firmly rooted in shared values and interests, is not workable because of the diversity of interests in the Northeast Asian region. ${ }^{234}$ Neither is the hegemony (balance-of-power) model an adequate model for the NEAC security network, ${ }^{235}$ for it would deepen the major power's skepticism. In the early stages of the NEAC, the "multi-layered network model" 236 would be reasonable, because multilateral security cooperation must be seen as a supplement, and not a replacement of existing bilateral relations, such as Korea-United States and United States-Japan. The first layer of such a model would consist of bilateral arrangements to deal with concrete security needs, because the existing Korea-United

232. See Begawan, supra note 103; see also Japan Ministry of Foreign Affairs Official Website, at http://www.mofa.go.jp (last visited Mar. 7, 2004).

233. See D. Lasok \& J.W. Bridge, Introduction to the LaW and Institution of the European Сомmunities 12-13 (3rd ed. 1982).

234. See Owada, supra note 212 , at 82 .

235. "Henry Kissinger . . claims that: 'Peace requires either hegemony or balance of power."' $I d$. at 83 .

236. See id. 
States and United States-Japan security relations are still important to regional stability. The second layer would be an NEAC political institution, like the early CSCE in $1975,{ }^{237}$ which would be intergovernmental and would have a political secretariat. Such an institution could deal with security issues by promoting a common policy and develop as a regional arrangement in the sense of Chapter VIII of the U.N. Charter. ${ }^{238}$ The third layer would be a broader multilateral security institution, which includes the United States, Russia, the EU, and the ASEAN. This third layer would be a regional framework for consultations on issues affecting common regional security interests. ${ }^{239}$ For this third layer, an already existing framework, such as the ASEAN Regional Forum (ARF) could be used. ${ }^{240}$ Concerning this NEAC security institution, the following things must be considered: the NEAC security integration should be accompanied by economic integration; a mature form of security integration needs time; ${ }^{241}$ with respect to regional security functions, even the most advanced form of regional security integration, namely the OSCE, is not based on treaty, but based on policy commitment; ${ }^{242}$ and security integration today must respond to today's demands, such as protecting human rights, ${ }^{243}$ and collective defense against global terrorism. ${ }^{244}$

237. See Marc Weller, The European Union within the 'European Security Architecture', in InTERnational Law Aspects of the European Union, supra note 120, at 78-80.

238. Regional arrangements for peace and security are recognized by the U.N. Charter. See U.N. Charter art. 53, para. 1.

239. See East Asia, supra note 1, at 6.

240. See East Asia Vision Group Report, supra note 31, at 17, para. 63. The first ARF meeting, in 1994, gathered foreign ministers of Australia, Brunei, Canada, China, the EU, Indonesia, Japan, Laos, Malaysia, New Zealand, PNG, Philippines, South Korea, Russia, Singapore, Thailand, the U.S. and Vietnam. The ARF's members are twenty-three countries, including Cambodia in 1995, India and Burma in 1996, Mongolia in 1999, and North Korea in 2000. See Australian Department of Foreign Affairs and Trade, ARF Membership, available at http://www.dfat.gov.au/ (last visited Mar. 7, 2004).

241. The CSCE was created in 1975 as a child of détente and as a result of Europe's combined security efforts after World War II; another twenty years had to pass before the OSCE was created in 1995 as a more developed form of CSCE. See Weller, supra note 237, at 78-82.

242. See id. at 82-83.

243. See Organization for Security and Co-operation in Europe, Summit Lisbon Document (Dec. 1996), available at http://www.osce.org/docs/.

244. See East Asia Vision Group Report, supra note 31. 


\section{Strong Dispute Settlement System (DSS)}

A well functioning community requires mechanisms to solve immediate disputes and to promote long-term community goals. ${ }^{245} \mathrm{~A}$ DSS in a regional integration would make the integration firm by interpreting and applying agreements on integration and community rules, just as the DSB of the WTO is "a central element in providing security and predictability to the multilateral trading system." ${ }^{246}$ Significant roles of the EU in the international system include effective dispute settlement and treaty enforcement in the process of economic integration as well as the role of removing trade barriers among its members. ${ }^{247}$ If there is a provision in a RTA between two countries (e.g., Korea and China) that asks for certain free trade measures from each country, it would be better for both countries to comply with the provision than if both breach it. If only one country breaches the provision, that country gets more benefits.

Figure 7 illustrates the hypothetical matrix ${ }^{248}$ namely the Prisoner's Dilemma, ${ }^{249}$ which does not change if a country breached a provision where there is not a strong form of DSS. ${ }^{250}$ Under a strong DSS that could provide sanctions ${ }^{251}$ against breach, and if the value of the sanction is (-4), the matrix will be changed as shown in parentheses. ${ }^{252}$ Such an analysis shows that a strong DSS

245. See Beth V. Yarbrough \& Robert M. Yarbrough, Dispute Settlement in International Trade: Regionalism and Procedural Coordination, in Political Economy of Regionalism, supra note 26, at $151-60$.

246. Philip I. Levy \& T.N. Srinivasan, Regionalism and the (Dis)advantage of Dispute-Settlement Access, in Trading Blocs: Alternative Approaches to Analyzing Preferential Trade AgreeMENTs, supra note 121 , at 534.

247. See JACKson ET AL., supra note 5, at 187.

248. See id. at 33-35, 187.

249. See Edgar K. Browning \& Jacqueline M. Browning, Microeconomic Theory and AppliCations 435-37 (4th ed. 1992); see also Hoekman \& Kostecki, supra note 43, at 109-10.

250. Two jurisdictional models can be inferred from the present international judicial system. The first model is the facultative jurisdiction of the International Court of Justice (ICJ) which depends on the party states, although the Statute of the Court includes an optional clause. See Statute of the International Court of Justice art. 34 para. 1 \& art. 36 para. 2. The other model is the obligatory jurisdiction of the European Court of Justice (ECJ) related to the subject issue of the EU treaty and its ability to hear various kinds of actions. See Craig \& de BúrCa, supra note 19, at 34; Barry E. Carter \& Phillip R. Trimble, International Law 363 (3d ed. 1999).

251. Even under a strong DSS, there remains the serious question of, "What is the sanction?" See Hoekman \& Kosteki, supra note 43, at 74-96.

252. See Yarbrough, supra note 245, at 134-38. 
Korea

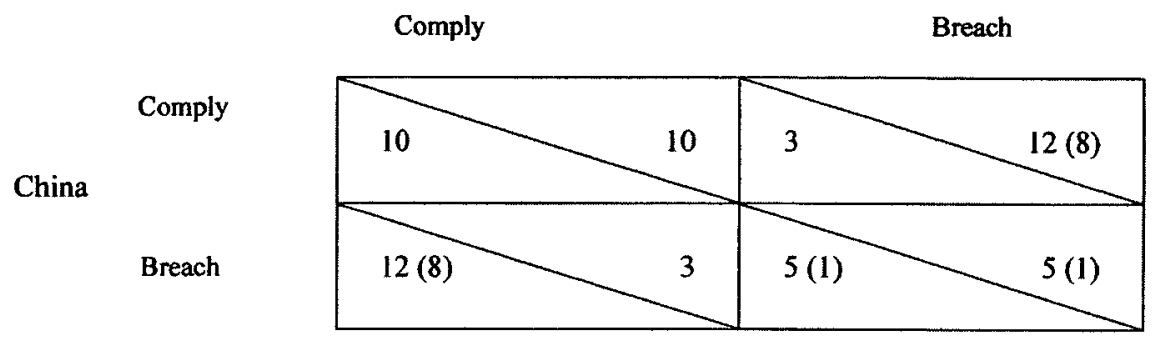

Figure 7: Hypothetical Matrix

could be a driving force for regional integration. ${ }^{253}$ Certainly, besides the European Court of Justice of the EU, many regional communities have obligatory jurisdictions. The Common Market for Eastern and Southern Africa has broad jurisdiction over inter-state disputes, as well as disputes between members and the Council. ${ }^{254}$ NAFTA $^{255}$ members wanted strong mechanisms for dispute settlement when they negotiated the establishing agreement. ${ }^{256}$

253. The Advocate-General of the ECJ gives the Court an independent opinion concerning cases by considering the EU's interests. John Collier \& Vaughan Lowe, The Settlement of Disputes in International Law: Institutions and Proceddures 105 (1999).

254. See Common Market for Eastern and Southern Africa (COMESA) Treaty, November 5 , 1993, art. 24, 33 I.L.M. 1067. The COMESA itself may take action against defaulting members. Any person, without restriction, may ask the Court to make a determination under the COMESA about its member's measures. See id. at arts. 25, 26. Also, the Court of the Economic Community of West African States (ECOWAS) has jurisdiction over disputes among members or between members and its institutions regarding the interpretation or application of the treaty. See Collier \& LowE, supra note 253, at 109-10.

255. The DSS of NAFTA is similar to that of the WTO. These systems are a mixed form of arbitration and litigation. See generally Ralph H. Folsom et al., NAFTA: A Problem-Oriented Course Book 425-41 (2000) (discussing the weight and status of dispute settlement with NAFTA). Parties must agree on the resolution of the dispute, in conformity with the determinations and recommendations of the final panel report. See North American Free Trade Agreement (NAFTA), Dec. 9, 1992, art. 2018, 32 I.L.M. 612, 697. The Free Trade Commission is empowered to deliver interpretations of the treaty to any domestic court in a member country, as a preliminary ruling of the ECJ. See id. at art. 2020. The panel's decisions concerning investor dispute and antidumping or countervailing duties are also binding. See id. at art. 1136 para. 1 \& art. 1904 para. 9.

256. Canada and Mexico wanted a strong DSS to monitor the United States' alleged abuse of trade laws. For Canada and the United States, a DSS eases worries that reliance on Mexico's legal system will weaken NAFTA's enforcement. See Gary Clyde Hufbauer \& Jeffrey J. Schott, North American Free Trade: Issues and Recommendations 37 (1992). 
The NEAC should adopt a strong form of DSS which can maintain the balance of power between the NEAC and the sovereignty of the members, and between the DSS and the economic institution. That means that the DSS of the NEAC should be a supranational institution like the NEAC economic institution.

\section{Conclusion}

As a regional substantial socio-economic integration under GATT article XXIV, the NEAC should be supranational, while maintaining members' sovereignty.

Given the empirical lessons from European integration, the trade diversion effect, or the decrease of welfare that would follow NEAC integration, is not serious. On the upward slope of supply curves, trade diversion improves the terms of trade of members relative to non-members. Even though the inside supply prices rise, it may increase the inside suppliers' surplus. Also, the net increase in product cost will be distributed inside the community, which may bring another gain in the unemployment situation. Freer flowing of inputs after regional integration also increases regional welfare.

The establishment of the NEAC will require regional identity, communications and transactions, and respect for the rest of the world. With various institutions for confidence-building and harmonization in the region, some institutions like the early form of European integrations should be built. A strong DSS would make the NEAC integration especially firm. 